\title{
Chronic pulsatile hyperglycemia reduces insulin secretion and increases accumulation of reactive oxygen species in fetal sheep islets
}

\author{
Alice S Green ${ }^{1}$, Xiaochuan Chen ${ }^{1}$, Antoni R Macko ${ }^{1}$, Miranda J Anderson ${ }^{1}$, Amy C Kelly ${ }^{1}$, \\ Nathaniel J Hart ${ }^{2}$, Ronald $\mathbf{M}$ Lynch $^{2}$ and Sean W Limesand ${ }^{\mathbf{1}}$ \\ Departments of ${ }^{1}$ Animal Sciences and ${ }^{2}$ Pharmacology and Physiology, University of Arizona, 1650 East Limberlost Drive, Tucson, Arizona 85719, USA \\ (Correspondence should be addressed to S W Limesand; Email: limesand@ag.arizona.edu)
}

\begin{abstract}
Children from diabetic pregnancies have a greater incidence of type 2 diabetes. Our objective was to determine if exposure to mild-moderate hyperglycemia, by modeling managed diabetic pregnancies, affects fetal $\beta$-cell function. In sheep fetuses, $\beta$-cell responsiveness was examined after 2 weeks of sustained hyperglycemia with 3 pulses/day, mimicking postprandial excursions, and compared to saline-infused controls $(n=10)$. Two pulsatile hyperglycemia (PHG) treatments were studied: mild (mPHG, $n=5$ ) with $+15 \%$ sustained and $+55 \%$ pulse; and moderate (PHG, $n=10$ ) with $+20 \%$ sustained and $+100 \%$ pulse. Fetal glucose-stimulated insulin secretion and glucose-potentiated arginine insulin secretion were lower $(P<0 \cdot 05)$ in PHG $(0.86 \pm 0.13$ and $2.91 \pm 0.39 \mathrm{ng} / \mathrm{ml}$ plasma insulin) but not in $\mathrm{mPHG}$ fetuses $(1.21 \pm 0.08$ and $4.25 \pm 0.56 \mathrm{ng} / \mathrm{ml})$ compared to controls $(1.58 \pm 0.25$ and $4.51 \pm 0.56 \mathrm{ng} / \mathrm{ml})$. Islet insulin content was
\end{abstract}

$35 \%$ lower in PHG and 35\% higher in $\mathrm{mPHG}$ vs controls $(P<0 \cdot 01)$. Insulin secretion and maximally stimulated insulin release were also reduced $(P<0 \cdot 05)$ in PHG islets due to lower islet insulin content. Isolated PHG islets also had 63\% greater $(P<0 \cdot 01)$ reactive oxygen species (ROS) accumulation at $11.1 \mathrm{mmol} / 1$ glucose than controls $(P<0 \cdot 01)$, but oxidative damage was not detected in islet proteins. PHG fetuses showed evidence of oxidative damage to skeletal muscle proteins $(P<0.05)$ but not insulin resistance. Our findings show that PHG induced dysregulation of islet ROS handling and decreased islet insulin content, but these outcomes are independent. The $\beta$-cell outcomes were dependent on the severity of hyperglycemia because mPHG fetuses had no distinguishable impairments in ROS handling or insulin secretion but greater insulin content.

Journal of Endocrinology (2012) 212, 327-342

\section{Introduction}

Diabetic conditions during pregnancy have been associated with an increased incidence of impaired glucose tolerance, insulin resistance, and type 2 diabetes in the offspring (Pettitt et al. 1985, Silverman et al. 1995, Plagemann et al. 1997, Dabelea et al. 2000, Sobngwi et al. 2003). Current clinical management guidelines allow pregnant mothers with diabetes to be mildly hyperglycemic, with fasting glucose $20-40 \%$ above normal, and to have larger postprandial excursions that are approximately twice the normal fasting glucose concentrations (Gillmer et al. 1975, Parretti et al. 2001, American Diabetes Association 2004, Siegmund et al. 2008). Fetal phenotypes, such as macrosomia, are strongly associated with maternal blood glucose concentrations (Karlsson \& Kjellmer 1972, Metzger et al. 2008), and postprandial glucose is more predictive of macrosomia than fasting glucose (JovanovicPeterson et al. 1991, Combs et al. 1992, de Veciana et al. 1995, Most \& Langer 2007). Fetal glucose is dependent on maternal concentrations; therefore, fetal exposure to chronic mild hyperglycemia with postprandial pulses appears to drive the adverse outcomes in offspring of diabetic pregnancies.
Although basal insulin is increased in human fetuses exposed to diabetic conditions (Silverman et al. 1995, Metzger et al. 2008 ), it is not known if $\beta$-cell responsiveness to glucose is affected. However, animal studies have shown that $\beta$-cell outcomes in offspring are dependent on the magnitude of hyperglycemic exposure (Aerts \& van Assche 1977, Kervran et al. 1978, Carver et al. 1996).

Oxidative stress is one possible mechanism for hyperglycemia-induced $\beta$-cell dysfunction. Reactive oxygen species (ROS) such as superoxide and hydrogen peroxide $\left(\mathrm{H}_{2} \mathrm{O}_{2}\right)$ are formed as byproducts of multiple metabolic pathways that are increased with hyperglycemia (Takahashi et al. 2004, Kaneto et al. 2005, Nakayama et al. 2005, Tsubouchi et al. 2005). In pregnant rats with severe hyperglycemia, oxidative stress increases embryological malformations and spontaneous abortions (Eriksson \& Borg 1993, Kinalski et al. 1999, Cederberg et al. 2001), and similar complications have been observed in women with severe pre-existing diabetes (Suhonen et al. 2000). Women with gestational diabetes also exhibit increased placental oxidative stress (Coughlan et al. 2004, Lappas et al. 2004); however, to our knowledge, fetal measures have not been obtained. Chronic oxidative stress in 
isolated islets and immortalized $\beta$-cell lines decreases glucosestimulated insulin secretion (GSIS) and lowers insulin content (Maechler et al. 1999, Kaneto et al. 2001, Noda et al. 2002, Tanaka et al. 2002, Sakai et al. 2003, Takahashi et al. 2004, Tang et al. 2007). Compared to other cell types, adult $\beta$-cells have relatively low levels of antioxidant enzymes and a limited ability to upregulate these enzymes in response to oxidative stress (Lenzen et al. 1996, Tiedge et al. 1997), therefore making them more vulnerable to oxidative stress. It is not yet known whether fetal $\beta$-cells possess similar deficiencies and vulnerability to ROS accumulation.

Another potential mechanism linking hyperglycemia and fetal $\beta$-cell dysfunction is endoplasmic reticulum (ER) stress. Abnormal proinsulin processing and protein folding induced by hyperglycemia can result in ER stress, distended rough ER, and insulin secretion defects (Araki et al. 2003). Distension of the ER was observed in $\beta$-cells of fetal rats subjected to an experimental model of gestational diabetes (Aerts \& van Assche 1977). ER stress would reflect possible defects caused by nitric oxide, calcium storage, or cytokines (Oyadomari \& Mori 2004).

We investigated insulin secretion responsiveness, islet function, islet ROS accumulation, and markers of ER stress in sheep fetuses exposed to chronic mild pulsatile hyperglycemia (mPHG). The sheep model was chosen for this study, because exogenous dextrose can be chronically infused into the pregnant ewe with precision in both magnitude and pattern (Carver et al. 1996). In vivo and ex vivo insulin responsiveness can be measured in the sheep fetus (Limesand et al. 2006, Green et al. 2011) and shares similarities with that in the human in during the progression of pancreas development (Green et al. 2010). Sheep fetuses were exposed to sustained mild-to-moderate hyperglycemia with three superimposed hyperglycemic pulses per day (mimicking postprandial excursions) for 2 weeks during late gestation. At the end of the treatment, GSIS was measured in the fetuses and their isolated pancreatic islets. Additionally, ROS accumulation in islets was measured in vitro, and markers of systemic oxidative stress and ER stress were assessed in fetal tissues. We found that PHG lowered islet insulin content and impaired fetal GSIS and ROS regulation, though these defects occured independently and were dependent on the magnitude of PHG.

\section{Materials and Methods}

\section{Animal preparation}

Pregnant Columbia-Rambouillet ewes carrying singletons were purchased from Nebeker Ranch Inc. (Lancaster, CA, USA) and managed in compliance with the Institutional Animal Care and Use Committee of the University of Arizona. All animal experiments were conducted at the William J Parker Agricultural Research Complex, Tucson, AZ, USA, which is accredited by the National Institutes of Health, the United States Department of Agriculture, and the
American Association for the Accreditation of Laboratory Animal Care. Animal rooms were maintained at $22 \pm 1{ }^{\circ} \mathrm{C}$ with a $14 \mathrm{~h}$ light:10 h darkness cycle. Except as noted below, food and water were available ad libitum, and food intake was recorded daily. Food was withheld for $24 \mathrm{~h}$ and water for $18 \mathrm{~h}$ prior to surgery. At $\sim 119$ dGA, fetuses were surgically instrumented with indwelling polyvinyl catheters as described previously (Limesand \& Hay 2003, Limesand et al. 2007). Fetal catheters for blood sampling were placed in the abdominal aorta via hind limb pedal arteries and infusion catheters were placed in the femoral veins via the saphenous veins. Maternal catheters were placed in the femoral artery for arterial sampling and the femoral vein for infusions. All catheters were tunneled subcutaneously to the ewe's flank, exteriorized through a skin incision, and kept in a plastic mesh pouch sutured to the ewe's skin. Ewes were given 4-5 days to recover from surgery before treatment.

\section{Study design}

Animals were randomly assigned to one of the three treatment groups: control $(n=10)$, mPHG $(n=5)$, and PHG $(n=10)$. Treatments were initiated at $124 \pm 0.5 \mathrm{dGA}$ with maternal i.v. infusions of $50 \%$ dextrose (weight/volume in $\mathrm{H}_{2} \mathrm{O}$ ) and were maintained for 14 days. In the $\mathrm{mPHG}$ and PHG animals, dextrose was infused to raise maternal plasma glucose concentrations 15 and 20\% above euglycemia (determined in control fetuses) respectively. Arterial plasma glucose concentrations were measured at least twice daily, and dextrose infusion rates were adjusted to maintain the specified treatment conditions. In addition, $\mathrm{mPHG}$ and $\mathrm{PHG}$ ewes received $45 \mathrm{~min}$ boluses of dextrose at 0800, 1400, and $2000 \mathrm{~h}$ each day at a rate sufficient to achieve peak plasma glucose concentrations 55 and 100\% above euglycemic values (compared to controls) respectively. The magnitude and pattern of the hyperglycemia treatments were specifically chosen to represent pregnant women with well-controlled diabetes ( $\mathrm{mPHG}$ ) and marginal glucose control (PHG), according to the current clinical guidelines (Carpenter \& Coustan 1982, American Diabetes Association 2004, Gilmartin et al. 2008). Plasma glucose concentrations during boluses were checked at least every other day and bolus infusion rates adjusted when needed. Control ewes were randomly paired to PHG ewes and received saline infusions of equal volumes. Maternal and fetal arterial blood samples were collected daily between 0700 and $0800 \mathrm{~h}$, and basal plasma glucose, lactate, and insulin, and blood gas and $\mathrm{pH}$ levels were measured. Seven maternal and fetal plasma samples (time 0-120 min) were collected for the 1400 h bolus on day 9 of treatment to quantify the fetal plasma insulin response to the boluses.

\section{GSIS and glucose-potentiated arginine-stimulated insulin secretion studies}

On day 13 or 14 of treatment, while continuing the chronic sustained maternal dextrose infusions and in place of the 
$0800 \mathrm{~h}$ bolus, GSIS was measured in nine control, five mPHG, and ten PHG fetuses with a square-wave hyperglycemic clamp as previously reported (Limesand et al. 2006, Green et al. 2011). Briefly, a continuous transfusion of maternal arterial blood into the fetus $(5 \mathrm{ml} / \mathrm{h})$ was started $45 \mathrm{~min}$ prior to baseline sampling and maintained for the duration of the study to compensate for blood collection. All sample times are presented relative to the start of the fetal glucose bolus and continuous glucose infusion at time 0. Basal period plasma glucose and insulin concentrations were determined at $-21,-13$, and $-5 \mathrm{~min}$. The hyperglycemic clamp was initiated with a dextrose bolus of $1 \cdot 19 \pm 0.04 \mathrm{mmol} / \mathrm{kg}$ estimated fetal weight to the fetus followed by a constant infusion of 33\% dextrose in saline to increase and maintain fetal arterial plasma glucose concentration at $2 \cdot 4 \mathrm{mmol} / \mathrm{l}$, which produces a near-maximal GSIS response in singleton sheep fetuses (Limesand et al. 2006, Green et al. 2011). At the onset of the glucose infusion, fetal arterial samples were collected every 5-10 min for the initial $30 \mathrm{~min}$ to establish the hyperglycemic steady state, after which fetal samples were collected at 45, 53, and $61 \mathrm{~min}$ (hyperglycemic period). At basal ( -21 to $-5 \mathrm{~min}$ ) and hyperglycemic (45-61 min) periods, blood gas and $\mathrm{pH}$ and plasma glucose, lactate, and insulin concentrations were measured. Following the 61 min hyperglycemic sample, a glucose-potentiated arginine-stimulated insulin secretion studies (GPAIS) test was conducted by injecting a bolus of arginine $(0.5 \mathrm{mmol} / \mathrm{kg}$ estimated fetal weight mixed with $1 \mathrm{ml}$ of $2 \mathrm{~mol} / \mathrm{l}$ sodium acetate and $4 \mathrm{ml}$ saline) over $4 \mathrm{~min}$ into the fetal circulation and collecting plasma samples at 5 , 15 , and $30 \mathrm{~min}$ for subsequent measurement of insulin concentrations.

\section{Biochemical analyses}

Blood gases, $\mathrm{pH}$, and oximetry parameters were measured in whole blood collected in heparin-lined syringes (Elkins-Sinn, Inc., Cherry Hill, NJ, USA) with an ABL 720 (Radiometer, Copenhagen, Denmark). Sample values were temperature corrected at $39 \cdot 1^{\circ} \mathrm{C}$. Whole blood collected in EDTA-lined syringes (Sigma-Aldrich) was centrifuged $(13000 \boldsymbol{g})$ for $2 \mathrm{~min}$ at $4{ }^{\circ} \mathrm{C}$, and the plasma was aspirated from the red blood cells. Plasma glucose and lactate concentrations were measured with a YSI Model 2700 SELECT Biochemistry Analyzer (Yellow Springs Instruments, Yellow Springs, OH, USA). The remaining plasma was stored at $-80^{\circ} \mathrm{C}$ until insulin was measured with an ovine insulin ELISA (ALPCO Diagnostics, Windham, NH, USA; intra-assay and interassay coefficients of variation (CV) were $5 \cdot 6$ and $2.9 \%$ respectively). In the control and PHG fetuses, remaining plasma from the -21 and $-13 \mathrm{~min}$ samples were pooled, and norepinephrine concentrations were analyzed by Noradrenaline ELISA (Labor Diagnostika Nord GmbH \& Co. KG, Nordhorn, Germany; intra-assay and interassay CV were 20 and $22 \%$ respectively).
Necropsy and islet isolation

Within $24 \mathrm{~h}$ of the GSIS studies, while remaining under treatment conditions, ewes and fetuses were killed with an i.v. overdose of sodium pentobarbital $(86 \mathrm{mg} / \mathrm{kg})$ and phenytoin sodium $(11 \mathrm{mg} / \mathrm{kg}$, Euthasol; Virbac Animal Health, Fort Worth, TX, USA). The fetus was blotted, dried and weighed. The fetal pancreas was perfused and digested with Liberase Blendzyme III $(0.175 \mathrm{mg} / \mathrm{ml}$; Roche $)$ in Krebs Ringer buffer (KRB; $118 \mathrm{mmol} / 1 \mathrm{NaCl}, 4 \cdot 8 \mathrm{mmol} / 1 \mathrm{KCl}, 2 \cdot 5 \mathrm{mmol} / 1 \mathrm{CaCl}_{2}$, $1.2 \mathrm{mmol} / 1 \mathrm{MgSO}_{4}, 1.2 \mathrm{mmol} / 1 \mathrm{KH}_{2} \mathrm{PO}_{4}, 25 \mathrm{mmol} / \mathrm{l}$ $\mathrm{NaHCO}_{3}, \mathrm{pH} 7 \cdot 3$ ) and then individual islets were purified as described previously (Limesand et al. 2006, Rozance et al. 2006, Leos et al. 2010). After removal, the pancreas, brain, liver, skeletal muscle, spleen, kidney, lung, heart, and perirenal adipose tissues were dissected and weighed. Liver (left lobe) and semitendinosus muscle samples were snap frozen in liquid nitrogen and stored at $-80{ }^{\circ} \mathrm{C}$ for $\mathrm{RNA}$ and protein extraction.

\section{Islet insulin secretion and glucose oxidation}

Isolated islets were cultured overnight at $37{ }^{\circ} \mathrm{C}$ in $95 \% \mathrm{O}_{2} /$ $5 \% \mathrm{CO}_{2}$ in RPMI-1640 medium (Sigma-Aldrich) supplemented with $2 \%$ fetal bovine serum (FBS), $2 \cdot 8 \mathrm{mmol} / 1$ glucose, and penicillin-streptomycin (50 $\mathrm{U}$ and $50 \mu \mathrm{g}$; Sigma-Aldrich). One day after isolation, in vitro experiments on islets were performed, and an aliquot of hand-picked islets was frozen and stored at $-80{ }^{\circ} \mathrm{C}$ for RNA and protein extraction.

In seven control, five mPHG, and eight PHG fetuses, insulin secretion was measured in static islet incubations (Limesand et al. 2006). Fetal islets were washed twice in KRB with $0.5 \% \mathrm{BSA}$ and a third time in KRB/BSA supplemented with $10 \mu \mathrm{mol} / 1$ Forskolin (Sigma-Aldrich) equilibrated to $37^{\circ} \mathrm{C}$ and $95 \% \mathrm{O}_{2} / 5 \% \mathrm{CO}_{2}$. Ten islets were hand-picked $\left(n=3-4\right.$ replicates/condition) and incubated at $37^{\circ} \mathrm{C}$ for $1 \mathrm{~h}$ in $\mathrm{KRB} / \mathrm{BSA} /$ Forskolin media with the following conditions: no glucose, $1.1 \mathrm{mmol} / 1$ glucose (nonstimulatory concentration), $11.1 \mathrm{mmol} / 1$ glucose (maximal glucose stimulatory concentration for fetal sheep islets (Limesand et al. 2006)), or $1 \cdot 1 \mathrm{mmol} / 1$ glucose plus $30 \mathrm{mmol} / 1 \mathrm{KCl}$. Negative control islet incubations in $11.1 \mathrm{mmol} / \mathrm{l}$ glucose on ice were included to evaluate cellular integrity. Following the incubation, islets were pelleted by centrifugation $(3 \mathrm{~min}$ at $800 \mathrm{~g}$ ) at $4{ }^{\circ} \mathrm{C}$. The media was removed and frozen, and islet insulin was extracted with acid-ethanol $(1 \mathrm{~mol} / 1 \mathrm{HCl} /$ $70 \%$ ethanol). Insulin concentrations were measured with the ovine insulin ELISA. The data were analyzed as nanogram insulin release per islet.

Rates of glucose oxidation were measured by the formation of ${ }^{14} \mathrm{CO}_{2}$ as previously described (Limesand et al. 2006) for islets from five control and five PHG fetuses; $\mathrm{mPHG}$ islets were not assessed. Twenty-five islets were handpicked into a $1 \mathrm{ml}$ cryotube affixed inside a scintillation vial and sealed. The islets were incubated for $2 \mathrm{~h}$ at $37^{\circ} \mathrm{C}$ in 
RPMI-1640 medium with 1\% FBS containing $1 \cdot 1$ or $11 \cdot 1 \mathrm{mmol} / 1$ D-glucose and $\left[\mathrm{U}_{-}{ }^{14} \mathrm{C}\right] \mathrm{D}$-glucose $(8$ or $16 \mu \mathrm{Ci} / \mathrm{ml}$ respectively; PerkinElmer, Boston, MA, USA).

\section{Islet ROS measurements}

Following isolation, islets were incubated overnight on glass cover slips precoated with human fibronectin $(10 \mathrm{mg} / \mathrm{l}$ in PBS; BD Biosciences, Bedford, MA, USA). Cover slips with adhered islets were transferred to a temperature-controlled chamber that was mounted on the stage of an Olympus IX-70 microscope (Center Valley, PA, USA). Islets were preloaded for $20 \mathrm{~min}$ at $37^{\circ} \mathrm{C}$ in HBSS containing $1.1 \mathrm{mmol} / 1$ glucose and $2 \mu \mathrm{mol} / 1$ of the ROS-sensitive probe $\mathrm{CM}-\mathrm{H}_{2} \mathrm{DCFDA}$ (Invitrogen). The media was then replaced with fresh $1.1 \mathrm{mmol} / 1$ glucose in HBSS $\left(37^{\circ} \mathrm{C}\right)$. Fluorescent images of a single islet were captured every minute with $100 \mathrm{~ms}$ exposures using a Photometrics (Tucson, AZ, USA) Coolsnap camera under the following sequence of conditions for $15 \mathrm{~min}$ each: $1.1 \mathrm{mmol} / 1$ glucose; $11.1 \mathrm{mmol} / 1$ glucose; and $11 \cdot 1 \mathrm{mmol} / \mathrm{l}$ glucose $+9 \mathrm{mmol} / 1 \mathrm{H}_{2} \mathrm{O}_{2}$ to evaluate the dynamic range of the probe. Preliminary experiments with both control and PHG islets in $1.1 \mathrm{mmol} / 1$ glucose showed a slow constant increase in fluorescence intensity for $60 \mathrm{~min}$, indicating a normal basal rate of $\mathrm{H}_{2} \mathrm{O}_{2}$ production regardless of fetal treatment. The rate of fluorescence increase at $1.1 \mathrm{mmol} / 1$ glucose was used to normalize rates during the hyperglycemic and $\mathrm{H}_{2} \mathrm{O}_{2}$ conditions in order to account for interislet variation in $\mathrm{CM}-\mathrm{H}_{2} \mathrm{DCFDA}$ loading. ROS measurements were obtained from two to five islets (5-10 ROI/islet) per fetal sheep and determined in eight control, three mPHG, and six PHG fetuses.

\section{Tissue preparation}

Total RNA was extracted from control and PHG liver and skeletal muscle tissues with Tri Reagent (Molecular Research Center, Inc. Cincinnati, OH, USA) and cleaned up using a QIAGEN Mini RNeasy column (Qiagen). Liver and skeletal muscle were homogenized in cold lysis buffer containing: 1\% Nonidet P-40, $150 \mathrm{mmol} / 1 \mathrm{NaCl}, 1 \mathrm{mM}$ EDTA, $1 \mathrm{mmol} / 1$

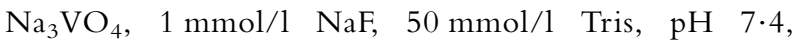
$0.5 \mathrm{mmol} / 1$ phenylmethylsulfonyl fluoride, $1 \mathrm{mM}$ dithiothreitol, $0.4 \mathrm{ng} / \mathrm{ml}$ aprotinin, and $6.3 \mu \mathrm{g} / \mathrm{ml}$ leupeptin. Protein lysates were centrifuged at $13000 \mathrm{~g}$ at $4{ }^{\circ} \mathrm{C}$ for $10 \mathrm{~min}$, and the supernatant was frozen and stored at $-80^{\circ} \mathrm{C}$. Total RNA and protein were extracted from purified islets of Langerhans using the Allprep DNA/RNA/Protein Mini Kit (Qiagen). RNA concentrations were determined by measuring absorbance at 260 and $280 \mathrm{~nm}$ (NanoDrop ND-1000 Spectrophotometer, Wilmington, DE, USA), and RNA integrity was confirmed with an Experion Automated Electrophoresis System (Bio-Rad Laboratories). Protein concentrations were determined with the BCA protein assay (Thermo Fisher Scientific, Inc., Rockford, IL, USA).
Tissue protein oxidative damage

Protein carbonyl incorporation was measured in skeletal muscle and liver from eight PHG and ten control fetuses and in islet protein lysates from six PHG and six control fetuses using the OxyBlot Protein Oxidation Detection Kit (Millipore, Billerica, MA, USA) following the manufacturer's instructions except as noted here. Five micrograms of islet protein and $7.5 \mu \mathrm{g}$ of liver and skeletal muscle protein lysates were derivatized to 2,4-dinitrophenylhydrazone (DNP) by reaction with 2,4-dinitrophenylhydrazine or were treated with a negative solution for a negative control. Proteins were separated on 10\% SDS-PAGE, transferred onto a polyvinylidene fluoride membrane (Bio-Rad), and blocked in the provided blocking/dilution buffer at room temperature for $1 \mathrm{~h}$. Immunoblot detection was achieved by overnight incubation at room temperature with the provided rabbit anti-DNP antibody. The primary antibody was detected with anti-rabbit IgG HRP conjugated secondary antibody $(1: 10000$; Bio-Rad) for $1 \mathrm{~h}$ at room temperature and detected using SuperSignal West Pico (Thermo Fisher Scientific) exposed to Kodak X-ray film. Because the density of individual bands did not change independently, the sum of the density of all DNP bands in each lane was quantified with ImageJ Software version 1.41 (National Institutes of Health, Bethesda, MD, USA). Multiple exposure times were analyzed to confirm that the films quantified were not saturated. Protein from each fetus was analyzed in triplicate, and paired control and PHG fetuses were analyzed on the same gel. In addition, protein from one select control fetus was included in triplicate on every gel, and the band density for all other lanes was normalized to the mean for the control protein.

\section{PCR and quantitative real-time PCR (qPCR)}

Synthetic oligonucleotide primers were designed against sequences for genes of interest (GenBank accession numbers are listed in parentheses and are for ovine sequences unless otherwise noted): antioxidants superoxide dismutase 1 (SOD-1; FJ546075), SOD-2 (GQ221055.1), GPx-1 (JF728302), catalase (GQ421282) and uncoupling protein 2 (UCP2; bovine sequence NM_001033611); insulin (U00659) and insulin transcription factors pancreatic and duodenal homeobox 1 (PDX-1; JF728303) and V-maf musculoaponeurotic fibrosarcoma oncogene homolog A (MafA; bovine sequence NM_001105637.1); ER stress response genes glucose regulatory protein-78 (GRP78; DQ029323), and DNA-damage inducible transcript-3 (DDIT-3; AY943948); and the reference gene ribosomal protein S15 (S15; AY949774) were designed with the aid of Primer-BLAST (NCBI, Bethesda, MD, USA) software and purchased from Eurofins MWG Operon (Huntsville, AL, USA) (primer sequences are available upon request). PCR products for ovine genes were amplified from fetal ovine mRNA by RT-PCR using Superscript III reverse transcriptase and Taq DNA polymerase (Qiagen) according to the manufacturer's instructions. Correct PCR products were 
verified by confirming product size after separation in a $1 \%$ agarose DNA gel. PCR products were then inserted into the TOPO TA cloning expression vector pCRII (Invitrogen) and transformed into One Shot Mach T1 Phage-Resistant Chemically Competent Escherichia coli (Invitrogen). Plasmids were prepared for nucleotide sequencing with a QIAprep Spin Miniprep Kit (Qiagen) and sequenced at the University of Arizona DNA Sequencing Service.

One microgram of RNA extracted from islets from nine control and five PHG fetuses was used to generate cDNA with SuperScript III Reverse Transcriptase (Invitrogen). The relative mRNA expression for each gene of interest was determined by qPCR using SYBR Green (Qiagen) in an iQ5 Real-Time PCR Detection System (Bio-Rad) as reported previously (Chen et al. 2010). After initial denaturation at $95^{\circ} \mathrm{C}$ for $15 \mathrm{~min}$, all reactions went through 40 cycles of $96{ }^{\circ} \mathrm{C}(30 \mathrm{~s})$, annealing temperature of $60-62{ }^{\circ} \mathrm{C}(30 \mathrm{~s})$, and $72^{\circ} \mathrm{C}(10 \mathrm{~s})$ at which point the fluorescence was measured. Melt curve analysis was performed at the end of the amplification to confirm product homogeneity. PCR efficiency was determined with islet cDNA (80-100\%) and was linear over six orders of magnitude. RNA samples were run in triplicate for each qPCR. The results were normalized to the reference gene $\mathrm{S} 15$ for each qPCR, and the average cycle threshold $\left(\Delta C_{\mathrm{T}}\right)$ was analyzed by the comparative $\Delta C_{\mathrm{T}}$ method $\left(C_{\mathrm{T}}\right.$ gene of interest $-C_{\mathrm{T}}$ reference gene) (Schmittgen \& Livak 2008).

\section{Western immunoblot analyses}

Western immunoblot analyses for SOD-1 and SOD-2, glutathione peroxidase $1 / 2(\mathrm{GPx}-1 / 2)$, insulin receptor- $\beta$ (IR $\beta), \beta$-tubulin, and ribosomal protein S6 were conducted as previously described (Chen et al. 2010) on liver and skeletal muscle protein preparations. Protein samples from each fetus were run in duplicate and $30 \mu \mathrm{g}$ protein were loaded per lane. Paired control and PHG fetuses were analyzed on the same gel, and protein from one control fetus was included in duplicate on every gel for the purposes of normalizing the band density from all other lanes on the gel. Ribosomal protein S6 was detected on a separate but identical gel loaded concurrently to test for equality of protein loading between animals. Immunoblot detection was accomplished with the following polyclonal antibodies purchased from Santa Cruz Biotechnology (Santa Cruz, CA, USA) unless otherwise noted: rabbit anti-SOD-1 (FL-154, sc-11407, diluted 1:1000); rabbit anti-SOD-2 (FL-222, sc-30080, diluted 1:1000); rabbit anti-GPx-1/2 (H-151, sc-30147, diluted 1:1000); rabbit anti-IR $\beta$ (C-19, sc-711, diluted 1:200); rabbit anti-ribosomal protein S6 (FL-249, sc-20085, diluted 1:200); and rabbit anti- $\beta$-tubulin (Thermo Scientific (Waltham, MA, USA), RB-9249-PO, diluted 1:1000).

\section{Statistical analysis}

All data are expressed as mean \pm s.E.M., and $P$ values $<0.05$ were considered significant. Data for feed and water intakes, maternal and fetal daily plasma values, organ weights, and qPCR were analyzed by one-way ANOVA and means compared with a Tukey's HSD test. Data from the fetal GSIS and islet insulin secretion experiments (including insulin contents) were subjected to an ANOVA with sheep as a random effect and treatment and period or treatment and media condition respectively as fixed effects. Differences were determined with an LSD test. In the GSIS, insulin responsiveness data had unequal variances, so a Welch's ANOVA was also run but gave the same results. Analysis for GPAIS was an ANOVA that accounted for the sheep as a random effect and draw and treatment as fixed effects (SAS GLM procedure). ROS data were analyzed by ANOVA with sheep as a random effect. Protein carbonyl data and other western immunoblot data were analyzed by paired $t$-test to determine differences between protein expression in paired control and PHG fetuses separated in the same gel. Statistical analyses were completed in JMP 8 and SAS 9.2 (SAS, Cary, NC, USA).

\section{Results}

\section{Maternal body weight and feed intake}

Before treatment, maternal body weight was not different between control $(44.2 \pm 1.7 \mathrm{~kg})$, PHG $(41.1 \pm 2.7 \mathrm{~kg})$, and $\mathrm{mPHG}$ ewes $(49 \cdot 9 \pm 3 \cdot 0 \mathrm{~kg})$. During the treatment period, feed intake was lower $(P<0 \cdot 01)$ in PHG ewes $(1.28 \pm 0.06 \mathrm{~kg} /$ day $)$ than $\mathrm{mPHG}(1.78 \pm 0.08 \mathrm{~kg} /$ day $)$ and control ewes $(1.84 \pm 0.07 \mathrm{~kg} /$ day $)$. However, total daily energy intake (feed + dextrose infusion) was not different between mPHG $(2 \cdot 88 \pm 0.13 \mathrm{Mcal} /$ day $)$ and PHG ewes $(2 \cdot 61 \pm 0 \cdot 10 \mathrm{Mcal} /$ day $)$, and both were greater than that of control ewes $(2 \cdot 26 \pm 0.09 \mathrm{Mcal} /$ day; $P<0 \cdot 01)$. In all treatments, energy intake was in excess of the requirements for maintenance and gestation (National Research Council 2007). Ewe body weight was included as a covariate in the analyses of feed and energy intake; the effect of body weight was significant for both parameters $(P<0 \cdot 01)$, but no interaction was found between body weight and treatment.

\section{Fetal body and organ weights}

At necropsy, average fetal body weights were similar between control $(3 \cdot 9 \pm 0 \cdot 2 \mathrm{~kg}), \mathrm{mPHG}(4 \cdot 3 \pm 0 \cdot 2 \mathrm{~kg})$, and PHG fetuses $(3 \cdot 6 \pm 0 \cdot 1 \mathrm{~kg})$. Fetal body weight was included as a covariate for all analyses of fetal organ weights, and no treatment effect was found for individual fetal organ weights (data not shown).

\section{Maternal and fetal plasma values during treatment}

Prior to treatment, maternal and fetal plasma glucose and fetal plasma insulin concentrations were not different between treatment groups (Table 1). Per our experimental design, the 
Table 1 Ovine maternal plasma glucose and lactate and fetal plasma glucose, lactate, and insulin prior to and during the treatment period. Values are means \pm S.E.M. Pretreatment and treatment values are the means from samples taken daily prior to the $0800 \mathrm{~h}$ bolus

\begin{tabular}{|c|c|c|c|}
\hline & Control & mPHG & PHG \\
\hline$n$ & 10 & 5 & 10 \\
\hline \multicolumn{4}{|l|}{ Pretreatment } \\
\hline Maternal glucose $(\mathrm{mmol} / \mathrm{l})$ & $3 \cdot 83 \pm 0 \cdot 06$ & $4 \cdot 07 \pm 0 \cdot 07$ & $3 \cdot 78 \pm 0 \cdot 09$ \\
\hline Fetal glucose $(\mathrm{mmol} / \mathrm{l})$ & $1 \cdot 19 \pm 0 \cdot 07$ & $1 \cdot 15 \pm 0 \cdot 07$ & $1 \cdot 11 \pm 0 \cdot 05$ \\
\hline Fetal insulin (ng/ml) & $0 \cdot 34 \pm 0 \cdot 04$ & $0.53 \pm 0.07$ & $0 \cdot 36 \pm 0 \cdot 05$ \\
\hline \multicolumn{4}{|l|}{ Treatment } \\
\hline Maternal glucose $(\mathrm{mmol} / \mathrm{l})$ & $3 \cdot 66 \pm 0 \cdot 04^{b}$ & $4 \cdot 22 \pm 0 \cdot 06^{\mathrm{a}}$ & $4 \cdot 39 \pm 0 \cdot 06^{\mathrm{a}}$ \\
\hline Fetal glucose $(\mathrm{mmol} / \mathrm{l})$ & $1 \cdot 07 \pm 0 \cdot 07^{\mathrm{b}}$ & $1 \cdot 23 \pm 0 \cdot 07^{\mathrm{a}, \mathrm{b}}$ & $1 \cdot 29 \pm 0 \cdot 06^{\mathrm{a}}$ \\
\hline Fetal insulin (ng/ml) & $0 \cdot 39 \pm 0 \cdot 05$ & $0.53 \pm 0.08$ & $0 \cdot 38 \pm 0 \cdot 05$ \\
\hline
\end{tabular}

Values not sharing the same letter within each row are different, $P<0 \cdot 05$.

magnitude and pattern of hyperglycemia were tightly controlled during the treatment period (Table 1 and Fig. 1). The interanimal $\mathrm{CV}$ in control, $\mathrm{mPHG}$, and $\mathrm{PHG}$ sheep respectively were $3 \cdot 2,4 \cdot 0$, and $3 \cdot 3 \%$ for maternal plasma glucose and $20 \cdot 7,13 \cdot 6$, and $13 \cdot 2$ for fetal plasma glucose. The within-animal $\mathrm{CV}$ for daily samples did not differ between treatments for either maternal (mean $5 \cdot 4 \pm 0 \cdot 4 \% ; P=0 \cdot 50$ ) or fetal plasma glucose concentrations (mean $8 \cdot 7 \pm 0 \cdot 7 \%$; $P=0 \cdot 26$ ). Basal maternal plasma glucose was $15 \pm 2 \%$ higher in $\mathrm{mPHG}$ ewes and $20 \pm 2 \%$ higher in PHG ewes than euglycemic controls $(P<0 \cdot 01$; Table 1 and Fig. 1). Fetal plasma glucose was $16 \pm 7$ and $21 \pm 5 \%$ higher in the $\mathrm{mPHG}$ and PHG fetuses respectively $(P<0 \cdot 05)$. Fetal insulin concentrations were not different between groups during the treatment period (Table 1).

At the peak of the boluses, plasma glucose concentrations were 1.56-fold higher than euglycemic control concentrations in $\mathrm{mPHG}$ ewes $(5 \cdot 72 \pm 0.09 \mathrm{mmol} / \mathrm{l})$ and fetuses $(1 \cdot 67 \pm 0 \cdot 10 \mathrm{mmol} / \mathrm{l}), 2 \cdot 03$-fold higher in $\mathrm{PHG}$ ewes $(7 \cdot 44 \pm 0.03 \mathrm{mmol} / \mathrm{l})$, and $2 \cdot 01$-fold higher in PHG fetuses $(2 \cdot 16 \pm 0.10 \mathrm{mmol} / 1 ; \quad P<0 \cdot 01 ;$ Fig. $1 \mathrm{C})$. Plasma insulin concentrations were increased $1 \cdot 40$-fold $(0 \cdot 74 \pm 0 \cdot 11 \mathrm{ng} / \mathrm{ml}$; $P<0 \cdot 05)$ in $\mathrm{mPHG}$ and 1.58 -fold $(1.60 \pm 0.07 \mathrm{ng} / \mathrm{ml}$; $P<0 \cdot 01)$ in PHG compared to basal values $(P<0 \cdot 05)$. The peak bolus glucose concentrations had interanimal $\mathrm{CV}$ of 3.5 and $7 \cdot 0 \%$ for maternal glucose and 13.9 and $12.5 \%$ for fetal glucose in $\mathrm{mPHG}$ and PHG animals respectively. The average within-animal $\mathrm{CV}$ (determined from at least six boluses on different days) were $6 \cdot 4 \pm 0 \cdot 5 \%$ for ewes and $8 \cdot 7 \pm 0 \cdot 7 \%$ for fetuses and were not different between treatments.

\section{Treatment infusion rates}

The amount of dextrose required to maintain basal maternal glucose at target concentrations increased during the treatment in the $\mathrm{mPHG}$ and PHG ewes (Fig. 2). The constant infusion rates on day 14 of treatment were $3 \cdot 6-$ and $2 \cdot 4$-fold higher than day 1 in the $\mathrm{mPHG}$ and $\mathrm{PHG}$ groups respectively, and the slopes of the infusion rates over time were positive for both treatments $(P<0 \cdot 01$; Fig. 2$)$. The bolus infusion rates also increased $1 \cdot 3$-fold (positive slope, $P<0 \cdot 01$ ) and $1 \cdot 1$-fold (slope $P=0 \cdot 12$ ) during the treatments, averaging $0 \cdot 17 \pm 0 \cdot 01$ and $0 \cdot 31 \pm 0.02 \mathrm{~g} / \mathrm{kg} \mathrm{BW}$ per $\mathrm{h}$ in the $\mathrm{mPHG}$ and $\mathrm{PHG}$ groups respectively.

\section{Hematological, lactate, and norepinephrine values during fetal GSIS}

Blood gases and blood $\mathrm{pH}$ were measured to evaluate physiological responses associated with hyperglycemia during the treatment and GSIS study. The fetal partial pressure of $\mathrm{CO}_{2}$ was greater in PHG fetuses $(51.50 \pm 0.18 \mathrm{mmHg} ; P<0.01$ for treatment effect) than controls $(49 \cdot 30 \pm 0 \cdot 21 \mathrm{mmHg})$, and $\mathrm{mPHG}$ fetuses $(49.99 \pm 0.23 \mathrm{mmHg})$ were not different from either control or PHG treatments. The $p \mathrm{CO}_{2}$ increased in the hyperglycemic period $(50 \cdot 80 \pm 0 \cdot 17 \mathrm{mmHg}, P<0 \cdot 01$ for period) vs basal $(49 \cdot 72 \pm 0 \cdot 17 \mathrm{mmHg})$, and there was no treatment by period interaction. Fetal blood oxygen content was not different between treatments but declined $(P<0 \cdot 01)$ during the GSIS hyperglycemic clamp $(3 \cdot 3 \pm 0 \cdot 5 \mathrm{mmol} / \mathrm{l})$ compared to the basal period $(3 \cdot 7 \pm 0 \cdot 10 \mathrm{mmol} / \mathrm{l})$. Average fetal arterial $\mathrm{pO}_{2}$ was $20 \cdot 8 \pm 0.9 \mathrm{mmHg}$ at basal and was unaffected by treatment or period. Fetal blood $\mathrm{pH}$ was also not affected by treatment, but $\mathrm{pH}$ was decreased $(P<0 \cdot 01)$ in the hyperglycemic period $(7 \cdot 35 \pm 0 \cdot 003)$ compared to basal period $(7 \cdot 37 \pm 0 \cdot 004)$. Maternal hematological parameters were not different between treatments (data not shown).

Differences within treatment and period were found for fetal plasma lactate concentrations, but no treatment by period interaction was observed. Plasma lactate concentrations were greater $(P<0 \cdot 01)$ in PHG fetuses $(2.63 \pm 0.03 \mathrm{mmol} / \mathrm{l})$ than $\mathrm{mPHG}$ fetuses $(2 \cdot 22 \pm 0 \cdot 04 \mathrm{mmol} / \mathrm{l})$ and both were greater $(P<0 \cdot 01)$ than control fetuses $(1 \cdot 88 \pm 0.03 \mathrm{mmol} / \mathrm{l})$. Plasma lactate concentrations increased $(P<0 \cdot 01)$ during the hyperglycemic clamp $(2.48 \pm 0.03 \mathrm{mmol} / \mathrm{l})$ from a basal period $(1.99 \pm 0.03 \mathrm{mmol} / \mathrm{l})$. Maternal plasma lactate concentrations were lower $(P<0 \cdot 05)$ in PHG ewes 


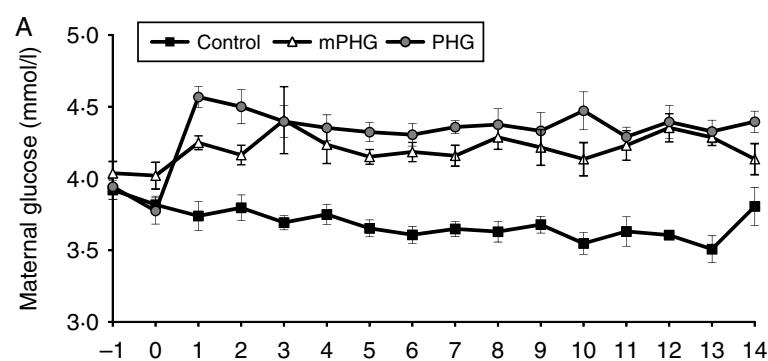

B
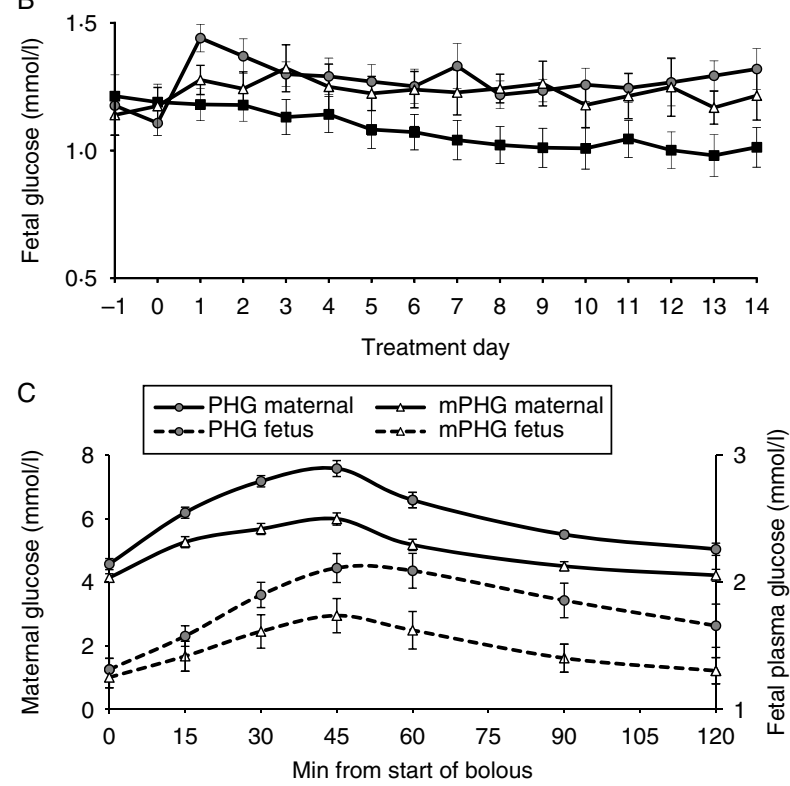

Figure 1 Maternal (A) and fetal (B) plasma glucose concentrations. Sustained mild ( $\mathrm{mPHG}$ ) or moderate (PHG) hyperglycemia was initiated on day 0 . Plasma was sampled prior to initiating treatment on day 0 and prior to the $0800 \mathrm{~h}$ dextrose pulse daily thereafter. Panel $\mathrm{C}$ shows maternal and fetal plasma glucose concentrations during the 45-min dextrose pulse administered at $1400 \mathrm{~h}$ on day 9 of treatment. The 2-h sampling period illustrates the magnitude and duration of hyperglycemia resulting from one of the dextrose pulses, which were given 3 times/day throughout the treatment period.

$(0 \cdot 45 \pm 0 \cdot 01 \mathrm{mmol} / \mathrm{l})$ than $\mathrm{mPHG}$ ewes $(0 \cdot 49 \pm 0 \cdot 01 \mathrm{mmol} / \mathrm{l})$ and were lower in both treatments than in controls $(0 \cdot 82 \pm 0 \cdot 01 \mathrm{mmol} / 1 ; \quad P<0 \cdot 01)$. The fetal hyperglycemic clamp did not alter maternal plasma lactate concentrations.

In the sheep fetus, norepinephrine in response to fetal stress has been shown to increase oxygen tension and lactate concentrations and decrease insulin secretion (Bassett \& Hanson 2000, Jackson et al. 2000). To confirm that adrenergic stimulation was not responsible for the hematological and metabolic responses described above, we measured fetal plasma norepinephrine concentrations during the basal period of the GSIS study (Jackson et al. 2000). Fetal norepinephrine concentrations were not different between control $(339 \pm 78 \mathrm{pg} / \mathrm{ml})$ and PHG fetuses $(402 \pm 182 \mathrm{pg} / \mathrm{ml}$; $P=0 \cdot 75)$.

\section{Fetal GSIS and GPAIS}

In the GSIS basal period fetal plasma glucose concentrations were not different from the treatment values reported above (Table 1 and Fig. 3). During the square-wave hyperglycemic clamp, glucose concentrations were increased to $2 \cdot 3 \pm 0 \cdot 2 \mathrm{mmol} / \mathrm{l}$, which was not different between treatments (Fig. 3A and B). Basal plasma insulin concentrations were not different between treatments and were 0.44 $\pm 0.08 \mathrm{ng} / \mathrm{ml}$ in control, $0.50 \pm 0.06 \mathrm{ng} / \mathrm{ml}$ in $\mathrm{mPHG}$, and $0 \cdot 42 \pm 0.07 \mathrm{ng} / \mathrm{ml}$ in PHG fetuses. At the hyperglycemic steady state, plasma insulin concentrations were lower $(P<0.05)$ in PHG fetuses $(0.86 \pm 0.13 \mathrm{ng} / \mathrm{ml})$ than control fetuses $(1 \cdot 58 \pm 0 \cdot 25 \mathrm{ng} / \mathrm{ml})$. Hyperglycemic insulin concentrations in the $\mathrm{mPHG}$ fetuses $(1 \cdot 21 \pm 0.08 \mathrm{ng} / \mathrm{ml})$ were not different from the control $(P<0.08)$ or PHG $(P<0.09)$ treatments. GSIS responsiveness was calculated as the difference between hyperglycemic and basal steady state plasma insulin concentrations. PHG fetuses had lower $(P<0 \cdot 05) \quad$ GSIS responsiveness $(0.45 \pm 0.07 \mathrm{ng} / \mathrm{ml})$ compared to controls $(1 \cdot 14 \pm 0.25 \mathrm{ng} / \mathrm{ml})$, while the mPHG fetuses were intermediate $(0.71 \pm 0.12 \mathrm{ng} / \mathrm{ml})$ and not different from either control or PHG fetuses (Fig. 3C and D). The fetal plasma insulin to glucose ratio did not differ between treatments during the basal period, but during the hyperglycemic clamp it was lower in PHG fetuses $(0.35 \pm 0.05 ; P<0.05)$ than in controls $(0.68 \pm 0.11) ; \mathrm{mPHG}$ fetuses $(0 \cdot 52 \pm 0 \cdot 03)$ were intermediate and not different from the other treatments (Fig. 3E).

Insulin concentrations following the arginine bolus reached maximum values after $5 \mathrm{~min}$ in all treatments (Fig. 4). Insulin concentrations during the GPAIS were lower in PHG fetuses than control and mPHG fetuses at both $5 \mathrm{~min}(P<0 \cdot 01)$ and $15 \mathrm{~min}(P<0 \cdot 05)$ following administration of arginine. The net incremental insulin area under the curve (AUC), when calculated from basal insulin concentrations, was lower in PHG fetuses $(P \leq 0 \cdot 05)$ than in control fetuses (Fig. 4B), reflecting impairment in the combined ability of glucose and arginine to enhance insulin secretion. In

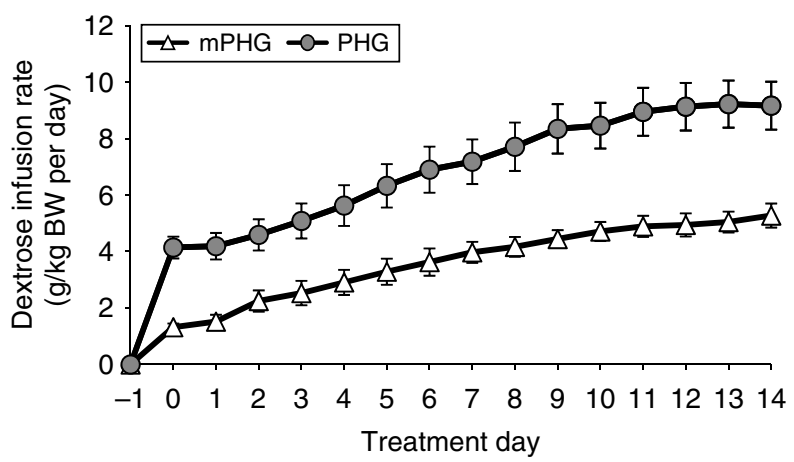

Figure 2 Dextrose infusion rates increase during $\mathrm{mPHG}$ and $\mathrm{PHG}$ treatment periods. Rates of dextrose infusion required to chronically maintain maternal plasma glucose 15\% (mPHG) and 20\% (PHG) above euglycemia increased during the course of the 14-day treatment. 

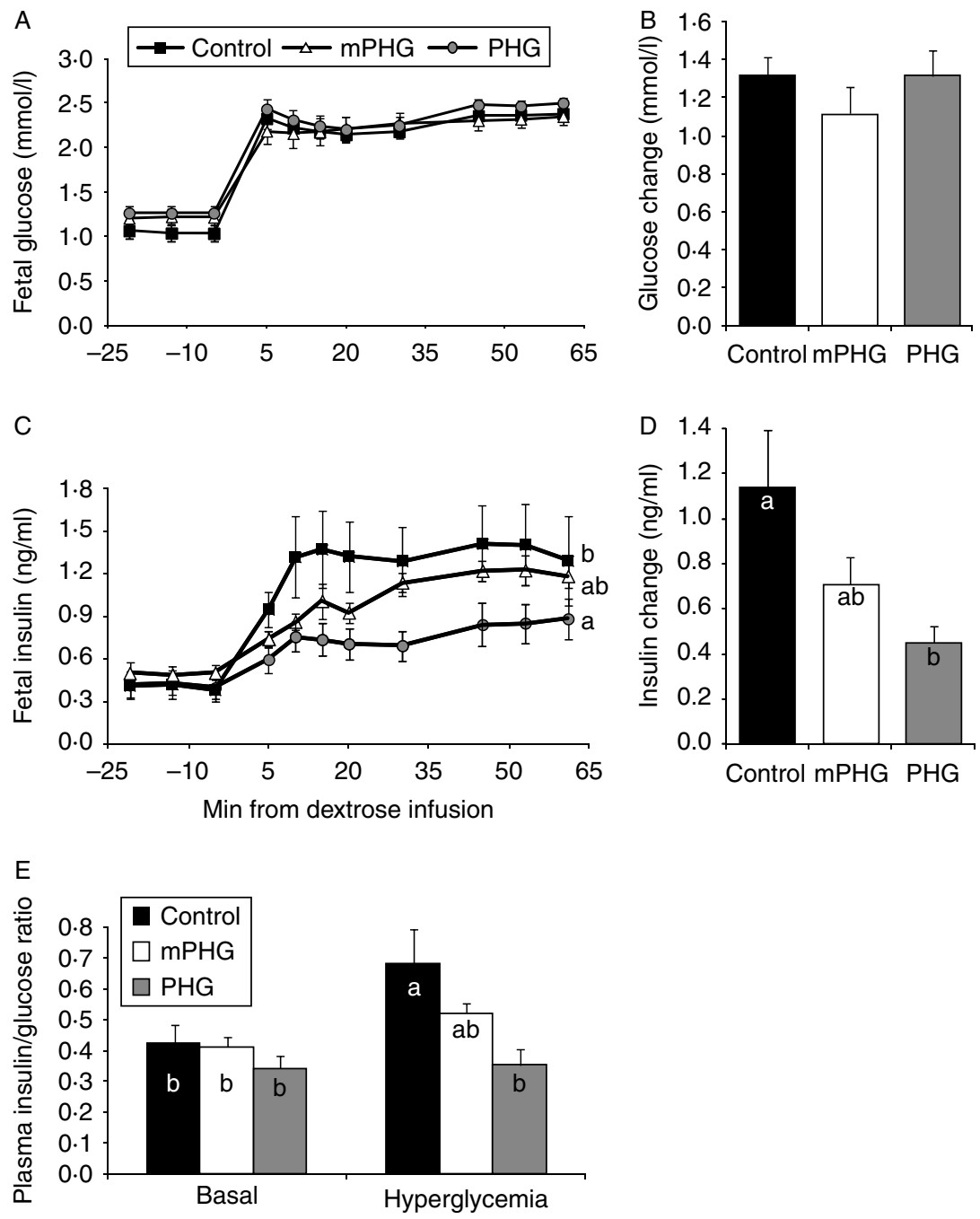

Figure 3 Impaired GSIS in PHG fetuses. Graphs A and C show mean plasma glucose and insulin concentrations during basal ( -21 to $0 \mathrm{~min}$ ) and hyperglycemic (after time 0 ) periods. The bar graphs show the changes in (B) glucose and (D) insulin between the basal and hyperglycemic (45-61 $\mathrm{min})$ steady state periods, which were calculated as the difference between hyperglycemia and basal mean concentrations. The elevation in glucose was similar between treatments, but PHG fetuses had a lower insulin response than control fetuses $(P<0 \cdot 05)$. Plasma insulin/glucose ratios (panel $E)$ are shown for basal and hyperglycemic steady state periods. Bars or plots not sharing the same letter are different, $P<0 \cdot 05$.

contrast, when net incremental AUC was calculated from the hyperglycemic steady state insulin concentrations, the AUC values were not different between groups $(P=0 \cdot 40$; not shown).

\section{Isolated islet insulin contents, insulin secretion, and glucose} oxidation

Islet insulin contents varied with treatment $(P<0 \cdot 05$; Fig. 5A); mPHG islets had greater insulin contents and PHG islets had lower insulin contents than control islets $(P<0 \cdot 05)$. Mean insulin release across the islet static incubations was reduced $(P<0 \cdot 05)$ in PHG islets
$(2 \cdot 1 \pm 0 \cdot 3 \mathrm{ng} /$ islet $)$ compared to control $(3 \cdot 2 \pm 0 \cdot 4 \mathrm{ng} /$ islet $)$ and $\mathrm{mPHG}$ islets $(3 \cdot 9 \pm 0 \cdot 4 \mathrm{ng} /$ islet), but control and $\mathrm{mPHG}$ means were not different. Among all treatments, insulin release was increased $(P \leq 0.05)$ in media conditions containing $11.1 \mathrm{mmol} / 1$ glucose $(2 \cdot 7 \pm 0.4 \mathrm{ng} /$ islet $)$ and $30 \mathrm{mmol} / 1 \mathrm{KCl}(8 \cdot 8 \pm 0 \cdot 4 \mathrm{ng} /$ islet $)$ compared to incubation conditions with 0 and $1 \cdot 1 \mathrm{mmol} / 1$ glucose $(1 \cdot 2 \pm 0 \cdot 4$ and $1 \cdot 4 \pm 0.4 \mathrm{ng} /$ islet; Fig. $5 \mathrm{~B})$. The only difference between treatment groups within an incubation condition was found in the $30 \mathrm{mmol} / 1 \mathrm{KCl}$ condition; insulin release in PHG islets was less $(P<0.05)$ than control and $\mathrm{mPHG}$ islets. Islets incubated on ice in $11.1 \mathrm{mmol} / 1$ glucose released equivalent 

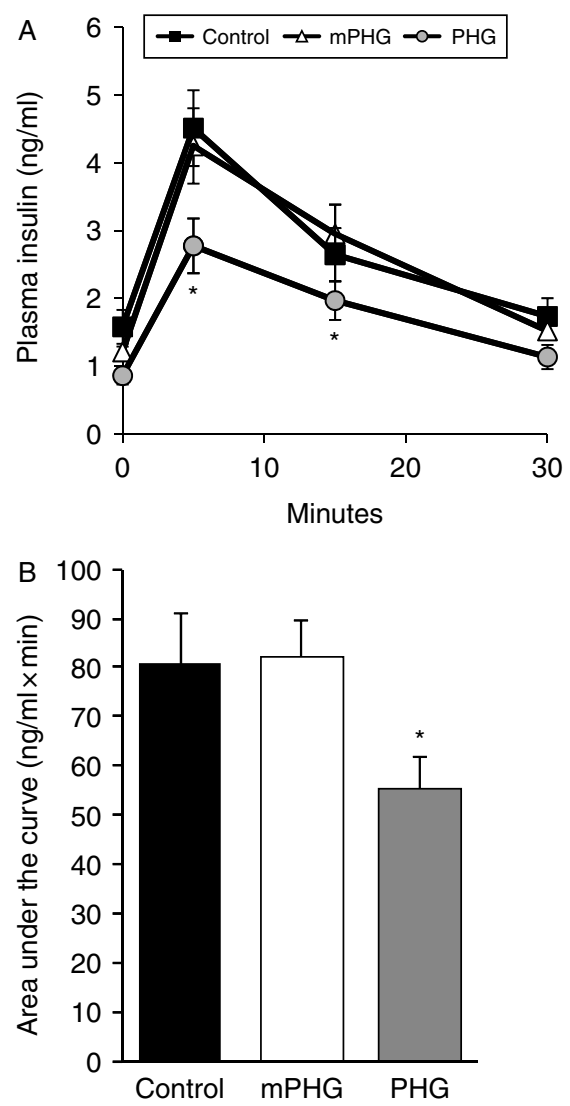

Figure 4 Impaired GPAIS in PHG fetuses. The follow-on arginine bolus administered at $\sim 65 \mathrm{~min}$ into the square-wave hyperglycemic clamp stimulated insulin secretion in all treatment groups and is presented relative to the start of the arginine infusion in panel $A$. An interaction between treatment and sample time $(P<0 \cdot 05)$ was found, and insulin concentrations were lower $(P<0 \cdot 05)$ in PHG fetuses at 5 and 15 min, indicated by the asterisks. In panel B, GPAIS AUC $(\mathrm{ng} / \mathrm{ml} \times \mathrm{min})$, calculated using basal steady state period insulin concentration as baseline, is reduced in PHG fetuses $\left({ }^{*} P \leq 0 \cdot 05\right)$.

amounts of insulin $(1 \cdot 4 \pm 0 \cdot 4 \mathrm{ng} /$ islet $)$ as islets in no glucose, demonstrating that insulin in the media was due to secretion and not cellular breakdown. Fractional insulin secretion, calculated as the percentage of total islet insulin released into the media, did not vary by treatment (data not shown).

The rate of glucose oxidation was measured in control and PHG islets. Stimulatory glucose concentrations $(11 \cdot 1 \mathrm{mmol} / \mathrm{l})$ increased the rate of glucose oxidative phosphorylation in isolated islets twofold $(8 \cdot 1 \pm 1 \cdot 2 \mathrm{pmol} /$ islet per h) compared to basal rates measured in $1.1 \mathrm{mmol} / \mathrm{l}$ glucose $(4 \cdot 1 \pm 0 \cdot 6 \mathrm{pmol} /$ islet per $\mathrm{h} ; P<0 \cdot 01)$. No differences between treatments were found.

\section{Islet ROS accumulation}

Fluorescence imaging of single isolated islets preloaded with $\mathrm{CM}-\mathrm{H}_{2} \mathrm{DCFDA}$ showed no difference between treatments in the rate of islet ROS accumulation at basal glucose concentrations $(1.1 \mathrm{mmol} / \mathrm{l})$; basal rates were $103 \pm 17$ a.u. $/ \mathrm{min}$ for control islets, $118 \pm 37$ a.u. $/ \mathrm{min}$ for mPHG islets, and $94 \pm 33$ a.u./min for PHG islets. Experimental intraislet variation due to $\mathrm{CM}-\mathrm{H}_{2}$ DCFDA loading was normalized to the basal rate in each individual islet to compare rates of ROS accumulation in the presence of stimulatory glucose and $\mathrm{H}_{2} \mathrm{O}_{2}$. Elevation of glucose from 1.1 to $11.1 \mathrm{mmol} / \mathrm{l}$ led to a $63 \%$ increase in the ROS accumulation rate in PHG islets, but there were no changes in control or $\mathrm{mPHG}$ islets. The relative glucose stimulated $(11.1 \mathrm{mmol} / \mathrm{l})$ rate of ROS accumulation was greater in PHG islets than control and mPHG islets $(P<0 \cdot 05$; Fig. 6). The subsequent addition of $9 \mathrm{mmol} / 1 \mathrm{H}_{2} \mathrm{O}_{2}$ further increased the rate of ROS accumulation similarly in all treatments (Fig. 6), showing that the dynamic range of the probe was not exceeded during the experiment. These data indicate that isolated PHG islets have a greater rate of ROS accumulation under stimulatory glucose conditions.

Islet gene expression for antioxidant enzymes, insulin expression, and ER stress

In isolated islets, relative mRNA expression levels for SOD-1, SOD-2, catalase, and GPx-1 were similar between treatments (Fig. 7), indicating that the greater glucose-stimulated ROS accumulation in PHG islets was caused by increased production of ROS rather than a change in enzymatic ROS clearance. In addition, mRNA expression levels for insulin, PDX-1, MafA, UCP2, and ER stress response genes (GRP78 and DDIT-3) were not different between control and PHG islets (Fig. 7). Islets from mPHG fetuses were not evaluated.

\section{Tissue protein oxidative stress, antioxidant enzymes, and $I R$}

We evaluated whether chronic PHG caused islet or systemic oxidative stress by measuring carbonyl incorporation of proteins, which is an indicator of protein oxidative damage. Skeletal muscle from PHG fetuses had $46 \%$ greater intensities for carbonyl moieties compared to control fetuses $(P<0 \cdot 05)$. However, there was no difference between PHG and control fetuses in carbonyl incorporation in liver or islet proteins. Protein concentrations of SOD1, SOD2, and GPx-1/2 in skeletal muscle and liver measured by western blot were not different between control and PHG treatments (Fig. 8A-D). Tissues from $\mathrm{mPHG}$ fetuses were not evaluated.

IR concentrations were measured in control and PHG insulin-sensitive tissues to evaluate whether receptormediated insulin clearance was enhanced by PHG exposure. No differences were found for IR concentrations in liver or skeletal muscle protein extracts (Fig. 8E and F).

\section{Discussion}

The objective of this study was to determine if 2 weeks of PHG exposure, similar to conditions in managed diabetic 

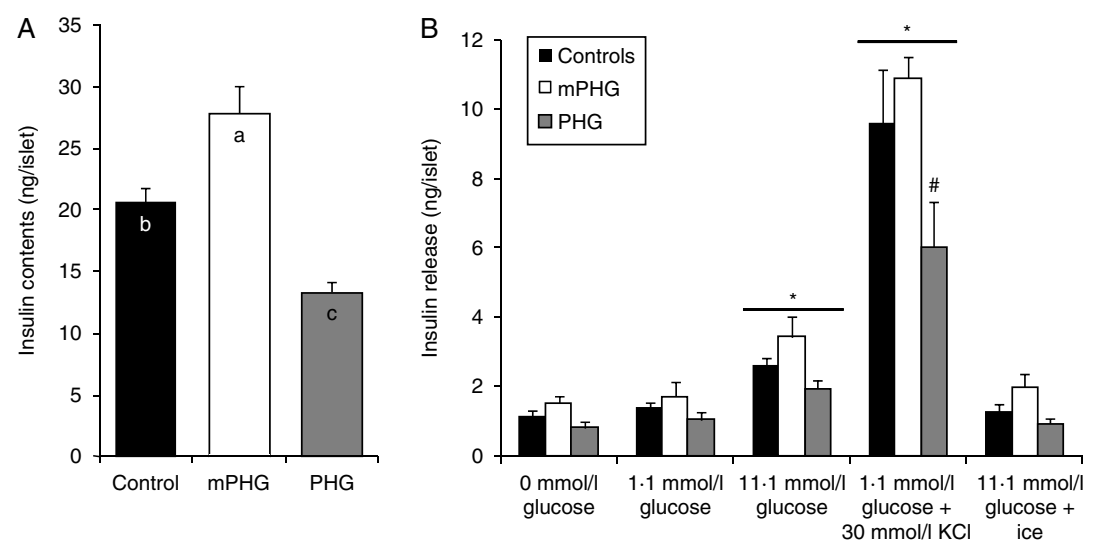

Figure 5 Decreased insulin content and release in PHG islets. In panel A, mean insulin content (ng/islet) is presented for islets isolated from control $(n=7), \mathrm{mPHG}(n=5)$, and PHG $(n=8)$ fetuses (indicated on the $x$-axis). Different letters indicate significant differences between values $(P<0.05)$. In panel $\mathrm{B}$, insulin release $(\mathrm{ng} / \mathrm{islet})$ is presented for static incubations in $\mathrm{KRB} / \mathrm{BSA}$ media containing $0 \mathrm{mmol} / \mathrm{l}$ glucose, $1 \cdot 1 \mathrm{mmol} / \mathrm{l}$ glucose, $11 \cdot 1 \mathrm{mmol} / \mathrm{l}$ glucose, $30 \mathrm{mmol} / \mathrm{I} \mathrm{KCl}$ and $1.1 \mathrm{mmol} / \mathrm{l}$ glucose, or $11.1 \mathrm{mmol} / \mathrm{l}$ glucose incubated on ice (indicated on the abscissa). Insulin release was increased in $11.1 \mathrm{mmol} / \mathrm{I}$ glucose and $30 \mathrm{mmol} / \mathrm{KCl}$ compared to incubation with 0 and $1.1 \mathrm{mmol} / \mathrm{l}$ glucose, and is indicated by the horizontal bars with an asterisk $(P<0 \cdot 05)$. In the $\mathrm{PHG}$ islets, $\mathrm{KCl}$ stimulated insulin release was less than control and $\mathrm{mPHG}$ islets, which is indicated with the number symbol $(P<0 \cdot 05)$.

pregnancies, would impact fetal $\beta$-cell responsiveness. The major finding was that PHG treatment attenuated fetal insulin secretion in response to glucose and glucose-potentiated arginine. The GPAIS study showed that the readily releasable pool of insulin was reduced in PHG fetuses compared to controls. Islets isolated from PHG fetuses also had reduced insulin content and insulin release. Moreover, maximal insulin release induced by depolarizing the islets with $\mathrm{KCl}$ was lower in PHG islets. These data, together with the fetal GPAIS results, indicate that insulin content was a limiting factor for PHG islets because both measures are dependent on $\beta$-cell insulin content or $\beta$-cell mass (Seaquist \& Robertson 1992, Robertson 2007). Fractional islet insulin release and islet glucose metabolism were not affected by PHG treatment, further supporting the hypothesis that reduced $\beta$-cell insulin content, rather than a defect in stimulus-secretion coupling, was the major factor explaining attenuated fetal GSIS. The second major finding of this study was that glucose-stimulated ROS accumulation was greater in the PHG islets, but there was no evidence for islet oxidative stress or ER stress. Therefore, oxidative stress does not appear to initiate the decline in insulin content; however, if persistent, it will cause islet oxidative damage and $\beta$-cell failure, as shown for adult models of hyperglycemia-induced diabetes (Kaneto et al. 1999, Tanaka et al. 1999, Tang et al. 2007). The major outcomes from PHG exposure were reduced fetal insulin secretion due to less insulin content and impaired islet ROS handling, but these two deficiencies do not appear to have a causal relationship.

The results of this study show that islet dysfunction is dependent on the magnitude of PHG. Strikingly, GSIS responsiveness was intermediate in $\mathrm{mPHG}$ fetuses, and the
mPHG response to the GPAIS study was not different from controls but greater than PHG fetuses. The mPHG islet insulin content was also greater than controls and, coupled with normal fetal GSIS, indicates insulin stimulus-secretion may be reduced. This is also supported in the islet experiments, because no enhancement of islet insulin secretion was observed even with elevated insulin content. Together, these findings indicate that within a narrow range of exposure to mild or moderate PHG, fetal $\beta$-cells exhibit impaired insulin stimulus-secretion with a compensatory increase in insulin contents ( $\mathrm{mPHG}$ ) or lower insulin contents (PHG), depending on the magnitude of hyperglycemia.

Insulin secretion responsiveness varies in human neonates born to diabetic mothers, and this variation is probably a result of differences in the duration and magnitude of exposure to hyperglycemia, as in our study and other animal studies described below. One human study showed no difference in infants' insulin responses to a glucose infusion (King et al. 1989). Others showed higher insulin concentrations in infants from diabetic mothers (Pildes et al. 1969, Obenshain et al. 1970, Pribylova \& Kozlova 1979), similar to the findings from our mPHG group, which had increased islet insulin content. Another study that directly measured insulin responsiveness to an i.v. glucose infusion in 2-h old infants of normal and diabetic mothers found that infants of diabetic mothers had a higher first phase but lower second phase insulin response (Isles et al. 1968), indicating $\beta$-cell dysfunction. Regardless, children of diabetic pregnancies exhibit an increased incidence of glucose intolerance (Pettitt et al. 1985, Silverman et al. 1995), and by the time these offspring reach their early twenties, they have compromised acute or early insulin secretion compared to control subjects (Gautier et al. 2001, 


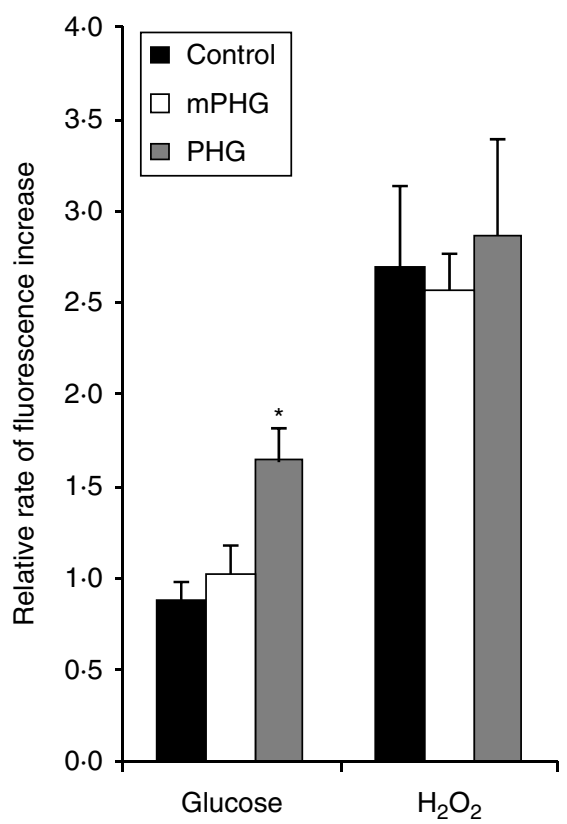

Figure 6 Greater glucose-stimulated ROS accumulation in PHG islets. In isolated fetal sheep islets, the fluorescence intensities from oxidation of the $\mathrm{CM}-\mathrm{H}_{2}$ DCFDA probe were determined in $1.1 \mathrm{mmol} / /$ glucose, $11.1 \mathrm{mmol} / \mathrm{l}$ glucose, and $9 \mathrm{mmol} / \mathrm{l} \mathrm{H}_{2} \mathrm{O}_{2}$ every minute for $15 \mathrm{~min}$ in each condition. Rates of ROS accumulation in stimulatory glucose and $\mathrm{H}_{2} \mathrm{O}_{2}$ were normalized to the basal rate $(1 \cdot 1 \mathrm{mmol} / \mathrm{l}$ glucose) for each islet, and the bars represent the mean \pm S.E.M. for two to five islets from each of eight control, five $\mathrm{mPHG}$, and six PHG fetuses. The asterisk indicates a significant difference $(P<0 \cdot 05)$ between control and PHG treatments in ROS accumulation at $11.1 \mathrm{mmol} / \mathrm{l}$ glucose.

Sobngwi et al. 2003). Together, these data support the notion that insulin secretion is programmed in utero, and our findings suggest that there is a narrow range of hyperglycemia within which either insulin secretion or production can be impaired. It should also be noted that basal glucose concentrations were not significantly different between the mPHG and PHG treatments in our study, but the pulsatile excursions were greater in the PHG treatment. Thus, differences in outcomes between the MPHG and PHG fetuses appear to be driven by the pulsatile excursions rather than chronic sustained hyperglycemia, an observation that has also been made in human studies (Jovanovic-Peterson et al. 1991, Combs et al. 1992, de Veciana et al. 1995, Most \& Langer 2007).

Other studies in pregnant sheep have evaluated effects of hyperglycemia on fetal insulin secretion. Carver et al. (1996) tested 10 days of chronic sustained hyperglycemia $(+35 \%)$ and a pulsatile treatment $(+17 \%$ sustained, $+60 \%$ pulses $3 \times /$ day) similar to our $\mathrm{mPHG}$ group. They found that the magnitude and pattern of hyperglycemia affected $\beta$-cell function differently, because insulin secretion was suppressed with chronic constant hyperglycemia and enhanced in the PHG treatment (Carver et al. 1995, 1996). In our study, insulin secretion was suppressed after 14 days of PHG treatment $(+20 \%$ sustained, $+100 \%$ pulses $3 \times /$ day $)$ but not mPHG treatment. We do not believe that this difference was due to duration of treatment, at least for the PHG fetuses, because comparison of the insulin: glucose ratio during one of the boluses on day 9 to the hyperglycemic clamp on day 14 , which reached similar glucose concentrations, showed no difference between days $9(0 \cdot 32 \pm 0 \cdot 03)$ and $14(0 \cdot 31 \pm 0 \cdot 03)$. This indicates that the lower insulin secretion responsiveness in PHG fetuses had occurred by 9 days. Therefore, PHG might exceed a threshold of severity of hyperglycemia, resulting in lower insulin secretion, as found in fetuses with $35 \%$ chronic sustained hyperglycemia (Carver et al. 1996). We found greater insulin content in islets isolated from mPHG fetuses compared to control fetuses, while PHG fetuses had less islet insulin content (Fig. 5). These data also reflect a $\beta$-cell response that is dependent on the magnitude of hyperglycemic exposure. In the milder PHG treatments by Carver $e t$ al., duration could still be a factor and the increased insulin production or $\beta$-cell mass, which appears to occur in mPHG islets, could occur initially in PHG islets. However, with continued hyperglycemic exposure, the $\beta$-cells become exhausted and insulin content decreases.

Rodent models of diabetic pregnancies generated by streptozotocin injections or direct glucose infusions have outcomes in offspring that are also dependent upon the severity of hyperglycemia. Severe hyperglycemia (usually $3-4 \times$ normal) in rat fetuses leads to $\beta$-cell degranulation and exhaustion, hypoinsulinemia, and impaired insulin secretion (Aerts \& van Assche 1977, Kervran et al. 1978). Postnatally, offspring have hypertrophy of the endocrine pancreas with an excess of small islets (Aerts et al. 1997) and are hypoglycemic and insulin resistant (Aerts \& Van Assche 1981, Holemans et al. 1991). In contrast, rat fetuses exposed to moderate hyperglycemia $(1 \cdot 3-2 \times$ normal $)$ have $\beta$-cell hyperplasia, increased insulin synthesis, and enhanced GSIS (Kervran et al. 1978, Aerts et al. 1997). However, withdrawal of

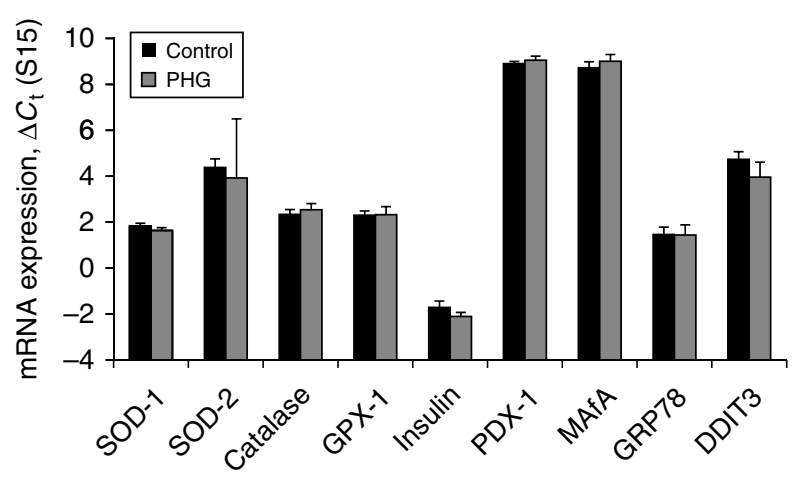

Figure 7 Islet gene expression for antioxidant enzymes, insulin, and ER stress. The mRNA expression normalized to ribosomal protein s15 is shown for enzymatic antioxidant defense (SOD-1, SOD-2, catalase, and GPx-1); insulin transcription (insulin, PDX-1, and MafA); and ER stress (GRP78 and DDIT3) in islets isolated from control and PHG fetuses. Values shown are calculated by the comparative $\Delta C_{\mathrm{T}}$ method ( $C_{\mathrm{T}}$ gene of interest $\times C_{\mathrm{T}}$ reference gene). Gene expression was not different between control and PHG islets. 

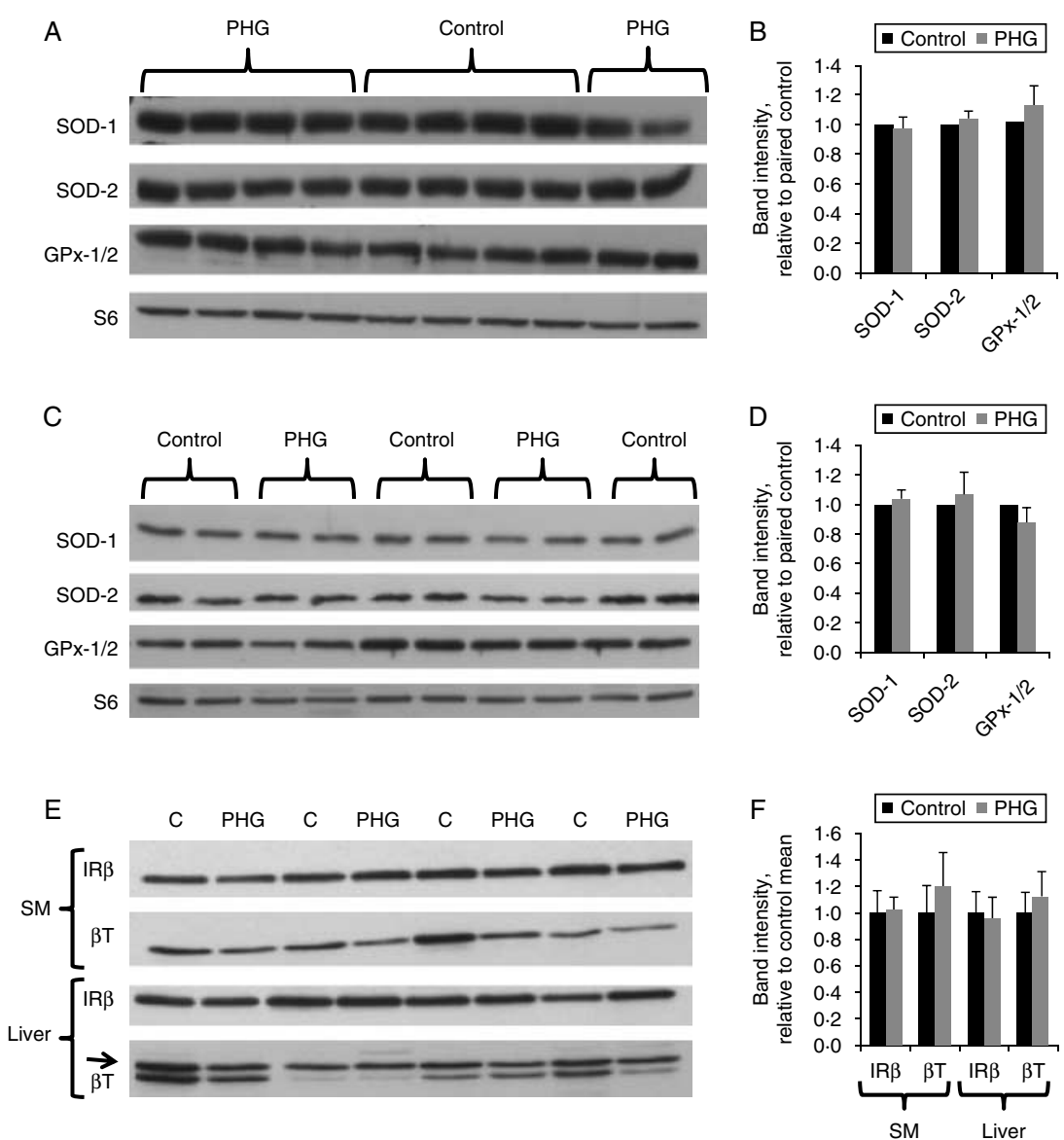

Figure 8 Antioxidant enzyme and insulin receptor concentrations in liver and skeletal muscle. Representative western immunoblots show protein concentrations of SOD-1, SOD-2, GPx-1/2, and the reference protein ribosomal protein S6, in (A and B) skeletal muscle and (C and D) liver and of insulin receptor $\beta$ and the reference protein $\beta$-tubulin in (E and F) skeletal muscle (SM) and liver (E and F). Bar graphs show quantification of band density by analysis in ImageJ. Antioxidant enzyme and insulin receptor $\beta$ protein concentrations were not different between control and PHG treatments. In panel E, C refers to control.

hyperglycemia after birth results in impaired GSIS with normal pancreatic endocrine mass and cell distribution at weaning (Bihoreau et al. 1986, Aerts et al. 1990, 1997, Gauguier et al. 1991, Van Assche et al. 2001, Boloker et al. 2002, Han et al. 2007). The work in rodent models further highlights differential outcomes resulting from moderate or severe hyperglycemia, similar to those found in our mPHG and PHG treatments, and it exemplifies the need for fetal evaluation of relevant hyperglycemic paradigms.

PHG islets demonstrated increased glucose-stimulated ROS accumulation compared to control or mPHG islets. Antioxidant enzyme expression was not different between control and PHG islets, indicating that the increased ROS accumulation was due to greater ROS production rather than impaired ROS clearance. It is worth noting that preliminary experiments in our laboratory indicate that overnight culture of fetal sheep islets, as was used in our study, induced a sixfold increase in the expression of SOD-2 (mitochondrial) and a threefold increase in GPx-1 expression. Thus, culture may be masking treatment effects on gene expression, but ROS accumulation was greater in PHG than control islets even after overnight culture and the presumed increased expression of antioxidant enzymes.

A direct link between decreased islet insulin content and increased islet ROS accumulation is not apparent. No differences in oxidative damage to islet proteins or UCP2 expression (Brand et al. 2010) were detected between control and PHG groups. However, we did find an increase in carbonyl incorporation in PHG skeletal muscle, which indicates higher systemic oxidative stress. Hyperglycemia and oxidative stress have been associated with vascular dysfunction in islets and other cell types (Koukkou et al. 1998, Teixeira \& Andrade 1999, Homo-Delarche et al. 2006, Segar et al. 2009), and defects in islet vasculature have been known to decrease insulin secretion (Eberhard et al. 2010, Richards et al. 2010). In the GK/Par spontaneous type 2 
diabetes rat model, oxidative stress markers are concentrated in the peri-islet vascular and inflammatory compartments (Lacraz et al. 2009). Defects in islet vasculature might explain the impairment of GSIS found in the fetus but not in isolated islets, as the isolation procedure would eliminate hemodynamic effects and might also prevent the detection of oxidative damage to peri-islet vasculature.

Although a direct mechanism linking ROS accumulation to impairment of insulin secretion in vivo has not been identified, increased ROS accumulation could represent an islet defect, which, if persistent, will cause oxidative damage and contribute to islet dysfunction in adulthood (Kaneto et al. 1999, Tanaka et al. 1999, Tang et al. 2007). In the GK/Par rat model, islets have greater ROS accumulation prior to the spontaneous onset of diabetes; after diabetes is evident, protective antioxidant enzymes are upregulated and oxidative damage is found in the pancreas (Lacraz et al. 2009). Chronic oxidative stress undermines the signaling potential of ROS and thus blunts insulin secretion function (Robertson \& Harmon 2006, Pi et al. 2007). Therefore, we predict that the observed increase in glucose-stimulated ROS accumulation in PHG islets foreshadows overt oxidative stress and the deterioration of islet insulin secretion.

The dextrose infusion rate increased during the 2-week PHG treatment in order to maintain chronic hyperglycemia in the pregnant ewe (Fig. 2), indicating improved maternal glucose disposal. If the PHG fetuses also have improved insulin sensitivity, they would have greater insulin clearance due to an upregulation of IRs (Flier et al. 1982, Mittelman et al. 2000). Although insulin clearance or insulin sensitivity was not directly measured in the current study, multiple lines of evidence indicate that insulin sensitivity is not a major factor for reduced insulin concentrations in PHG fetuses. No differences were found in insulin to glucose ratios during basal treatment conditions (Fig. 3E). Insulin clearance following the arginine bolus was not different between treatments, though it tended $(P=0.075)$ to be lower in PHG $(-0.65 \pm 0.01 \mathrm{ng} / \mathrm{ml})$ than control $(-0.107 \pm 0.02 \mathrm{ng} / \mathrm{ml})$ or mPHG $(-0 \cdot 108 \pm 0 \cdot 02)$ fetuses. Finally, in liver and skeletal muscle, IR concentrations were not different between control and PHG fetuses (Fig. 8). These findings indicate that lower plasma insulin concentrations following the GSIS or GPAIS challenge were due to decreased insulin secretion and not increased clearance, which is also supported by isolated islet experiments (Fig. 5).

In the current study, fetal insulin secretion was impaired following a 2-week regimen of PHG during late gestation. The PHG treatment was designed to replicate the magnitude and pattern of glycemic control found in pregnant women with diabetes managed under the current clinical guidelines. However, many women do not attain this degree of glycemic control during their pregnancies, and in these cases of fetal exposure to more severe hyperglycemia, the outcomes are likely worse. Islet ROS accumulation appears to occur independently of the impairment in insulin secretion, but if this defect persists, we expect it to cause further damage to islet function. Because of the clinical relevance of the PHG treatment regimen and the resulting diabetic phenotype in fetal offspring, additional work with this model will be useful in investigating the mechanisms for the association of fetal exposure to hyperglycemia and diabetes risk later in life.

\section{Declaration of interest}

The authors declare that there is no conflict of interest that could be perceived as prejudicing the impartiality of the research reported.

\section{Funding}

The project described was supported by Competitive Advantage Award CAA 0230-08 from the Science Foundation of Arizona (Award Number R01 DK084842) (Principle Investigator S W L) from the National Institute of Diabetes and Digestive and Kidney Diseases, and an Endocrine Society Bridge Grant (Principle Investigator S W L). The content is solely the responsibility of the authors and does not necessarily represent the official views of the National Institute of Diabetes and Digestive and Kidney Diseases or the National Institutes of Health. A S G was supported by T32 HL7249 and F32 DK088514. A R M was supported by T32 HL7249.

\section{Acknowledgements}

We are grateful to Mandie M Dunham, Craig S Weber, and Devora Magier for their technical assistance.

\section{References}

Aerts L \& van Assche FA 1977 Rat foetal endocrine pancreas in experimental diabetes. Journal of Endocrinology 73 339-346. (doi:10.1677/joe.0.0730339)

Aerts L \& Van Assche FA 1981 Endocrine pancreas in the offspring of rats with experimentally induced diabetes. Journal of Endocrinology 88 81-88. (doi:10.1677/joe.0.0880081)

Aerts L, Holemans K \& Van Assche FA 1990 Maternal diabetes during pregnancy: consequences for the offspring. Diabetes/Metabolism Reviews 6 147-167. (doi:10.1002/dmr.5610060303)

Aerts L, Vercruysse L \& Van Assche FA 1997 The endocrine pancreas in virgin and pregnant offspring of diabetic pregnant rats. Diabetes Research and Clinical Practice 38 9-19. (doi:10.1016/S0168-8227(97)00080-6)

American Diabetes Association 2004 Gestational diabetes mellitus. Diabetes Care 27 S88-S90. (doi:10.2337/diacare.27.2007.S88)

Araki E, Oyadomari S \& Mori M 2003 Impact of endoplasmic reticulum stress pathway on pancreatic beta-cells and diabetes mellitus. Experimental Biology and Medicine 228 1213-1217.

Bassett JM \& Hanson C 2000 Prevention of hypoinsulinemia modifies catecholamine effects in fetal sheep. American Journal of Physiology. Regulatory, Integrative and Comparative Physiology 278 R1171-R1181.

Bihoreau MT, Ktorza A, Kervran A \& Picon L 1986 Effect of gestational hyperglycemia on insulin secretion in vivo and in vitro by fetal rat pancreas. American Journal of Physiology 251 E86-E91.

Boloker J, Gertz SJ \& Simmons RA 2002 Gestational diabetes leads to the development of diabetes in adulthood in the rat. Diabetes 51 1499-1506. (doi:10.2337/diabetes.51.5.1499)

Brand MD, Parker N, Affourtit C, Mookerjee SA \& Azzu V 2010 Mitochondrial uncoupling protein 2 in pancreatic beta-cells. Diabetes, Obesity \& Metabolism 12 (Suppl 2) 134-140. (doi:10.1111/j.1463-1326. 2010.01264.x) 
Carpenter MW \& Coustan DR 1982 Criteria for screening tests for gestational diabetes. American Journal of Obstetrics and Gynecology 144 768-773.

Carver TD, Anderson SM, Aldoretta PA, Esler AL \& Hay WW Jr 1995 Glucose suppression of insulin secretion in chronically hyperglycemic fetal sheep. Pediatric Research 38 754-762. (doi:10.1203/00006450-19951100000020)

Carver TD, Anderson SM, Aldoretta PW \& Hay WW Jr 1996 Effect of low-level basal plus marked "pulsatile" hyperglycemia on insulin secretion in fetal sheep. American Journal of Physiology 271 E865-E871.

Cederberg J, Basu S \& Eriksson UJ 2001 Increased rate of lipid peroxidation and protein carbonylation in experimental diabetic pregnancy. Diabetologia 44 766-774. (doi:10.1007/s001250051686)

Chen X, Fahy AL, Green AS, Anderson MJ, Rhoads RP \& Limesand SW 2010 beta2-Adrenergic receptor desensitization in perirenal adipose tissue in fetuses and lambs with placental insufficiency-induced intrauterine growth restriction. Journal of Physiology 588 3539-3549. (doi:10.1113/ jphysiol.2010.192310)

Combs CA, Gunderson E, Kitzmiller JL, Gavin LA \& Main EK 1992 Relationship of fetal macrosomia to maternal postprandial glucose control during pregnancy. Diabetes Care 15 1251-1257. (doi:10.2337/diacare.15. 10.1251)

Coughlan MT, Vervaart PP, Permezel M, Georgiou HM \& Rice GE 2004 Altered placental oxidative stress status in gestational diabetes mellitus. Placenta 25 78-84. (doi:10.1016/S0143-4004(03)00183-8)

Dabelea D, Hanson RL, Lindsay RS, Pettitt DJ, Imperatore G, Gabir MM, Roumain J, Bennett PH \& Knowler WC 2000 Intrauterine exposure to diabetes conveys risks for type 2 diabetes and obesity: a study of discordant sibships. Diabetes 49 2208-2211. (doi:10.2337/diabetes.49.12.2208)

Eberhard D, Kragl M \& Lammert E 2010 'Giving and taking': endothelial and beta-cells in the islets of Langerhans. Trends in Endocrinology and Metabolism 21 457-463. (doi:10.1016/j.tem.2010.03.003)

Eriksson UJ \& Borg LA 1993 Diabetes and embryonic malformations. Role of substrate-induced free-oxygen radical production for dysmorphogenesis in cultured rat embryos. Diabetes 42 411-419. (doi:10.2337/diabetes.42.3. 411)

Flier JS, Minaker KL, Landsberg L, Young JB, Pallotta J \& Rowe JW 1982 Impaired in vivo insulin clearance in patients with severe target-cell resistance to insulin. Diabetes 31 132-135. (doi:10.2337/diabetes.31.2.132)

Gauguier D, Bihoreau MT, Picon L \& Ktorza A 1991 Insulin secretion in adult rats after intrauterine exposure to mild hyperglycemia during late gestation. Diabetes 40 (Suppl 2) 109-114.

Gautier JF, Wilson C, Weyer C, Mott D, Knowler WC, Cavaghan M, Polonsky KS, Bogardus C \& Pratley RE 2001 Low acute insulin secretory responses in adult offspring of people with early onset type 2 diabetes. Diabetes 50 1828-1833. (doi:10.2337/diabetes.50.8.1828)

Gillmer MD, Beard RW, Brooke FM \& Oakley NW 1975 Carbohydrate metabolism in pregnancy. Part I. Diurnal plasma glucose profile in normal and diabetic women. BMJ 3 399-402. (doi:10.1136/bmj.3.5980.399)

Gilmartin AB, Ural SH \& Repke JT 2008 Gestational diabetes mellitus. Reviews in Obstetrics and Gynecology 1 129-134.

Green AS, Rozance PJ \& Limesand SW 2010 Consequences of a compromised intrauterine environment on islet function. Journal of Endocrinology 205 211-224. (doi:10.1677/JOE-09-0399)

Green AS, Macko AR, Rozance PJ, Yates DT, Chen X, Hay WW Jr \& Limesand SW 2011 Characterization of glucose-insulin responsiveness and impact of fetal number and gender on insulin response in the sheep fetus. American Journal of Physiology. Endocrinology and Metabolism 300 E817-E823. (doi:10.1152/ajpendo.00572.2010)

Han J, Xu J, Long YS, Epstein PN \& Liu YQ 2007 Rat maternal diabetes impairs pancreatic beta-cell function in the offspring. American Journal of Physiology. Endocrinology and Metabolism 293 E228-E236. (doi:10.1152/ ajpendo.00479.2006)

Holemans K, Aerts L \& Van Assche FA 1991 Evidence for an insulin resistance in the adult offspring of pregnant streptozotocin-diabetic rats. Diabetologia 34 81-85. (doi:10.1007/BF00500377)
Homo-Delarche F, Calderari S, Irminger JC, Gangnerau MN, Coulaud J, Rickenbach K, Dolz M, Halban P, Portha B \& Serradas P 2006 Islet inflammation and fibrosis in a spontaneous model of type 2 diabetes, the GK rat. Diabetes 55 1625-1633. (doi:10.2337/db05-1526)

Isles TE, Dickson M \& Farquhar JW 1968 Glucose tolerance and plasma insulin in newborn infants of normal and diabetic mothers. Pediatric Research 2 198-208. (doi:10.1203/00006450-196805000-00007)

Jackson BT, Piasecki GJ, Cohn HE \& Cohen WR 2000 Control of fetal insulin secretion. American Journal of Physiology. Regulatory, Integrative and Comparative Physiology 279 R2179-R2188.

Jovanovic-Peterson L, Peterson CM, Reed GF, Metzger BE, Mills JL, Knopp RH \& Aarons JH 1991 Maternal postprandial glucose levels and infant birth weight: the Diabetes in Early Pregnancy Study. The National Institute of Child Health and Human Development-Diabetes in Early Pregnancy Study. American Journal of Obstetrics and Gynecology 164 103-111.

Kaneto H, Kajimoto Y, Miyagawa J, Matsuoka T, Fujitani Y, Umayahara Y, Hanafusa T, Matsuzawa Y, Yamasaki Y \& Hori M 1999 Beneficial effects of antioxidants in diabetes: possible protection of pancreatic beta-cells against glucose toxicity. Diabetes 48 2398-2406. (doi:10.2337/diabetes.48.12. 2398)

Kaneto H, Xu G, Song KH, Suzuma K, Bonner-Weir S, Sharma A \& Weir GC 2001 Activation of the hexosamine pathway leads to deterioration of pancreatic beta-cell function through the induction of oxidative stress. Journal of Biological Chemistry 276 31099-31104. (doi:10.1074/jbc. M104115200)

Kaneto H, Kawamori D, Matsuoka TA, Kajimoto Y \& Yamasaki Y 2005 Oxidative stress and pancreatic beta-cell dysfunction. American Journal of Therapeutics 12 529-533. (doi:10.1097/01.mjt.0000178773.31525.c2)

Karlsson K \& Kjellmer I 1972 The outcome of diabetic pregnancies in relation to the mother's blood sugar level. American Journal of Obstetrics and Gynecology 112 213-220.

Kervran A, Guillaume M \& Jost A 1978 The endocrine pancreas of the fetus from diabetic pregnant rat. Diabetologia 15 387-393. (doi:10.1007/ BF01219648)

Kinalski M, Sledziewski A, Telejko B, Zarzycki W \& Kinalska I 1999 Antioxidant therapy and streptozotocin-induced diabetes in pregnant rats. Acta Diabetologica 36 113-117. (doi:10.1007/s005920050153)

King KC, Oliven A \& Kalhan SC 1989 Functional enteroinsular axis in full-term newborn infants. Pediatric Research 25 490-495. (doi:10.1203/ 00006450-198905000-00013)

Koukkou E, Ghosh P, Lowy C \& Poston L 1998 Offspring of normal and diabetic rats fed saturated fat in pregnancy demonstrate vascular dysfunction. Circulation 98 2899-2904. (doi: 10.1161/01.CIR.98.25.2899)

Lacraz G, Figeac F, Movassat J, Kassis N, Coulaud J, Galinier A, Leloup C, Bailbe D, Homo-Delarche F \& Portha B 2009 Diabetic beta-cells can achieve self-protection against oxidative stress through an adaptive up-regulation of their antioxidant defenses. PLoS ONE 4 e6500. (doi:10. 1371/journal.pone.0006500)

Lappas M, Permezel M \& Rice GE 2004 Release of proinflammatory cytokines and 8-isoprostane from placenta, adipose tissue, and skeletal muscle from normal pregnant women and women with gestational diabetes mellitus. Journal of Clinical Endocrinology and Metabolism 89 5627-5633. (doi:10.1210/jc.2003-032097)

Lenzen S, Drinkgern J \& Tiedge M 1996 Low antioxidant enzyme gene expression in pancreatic islets compared with various other mouse tissues. Free Radical Biology \& Medicine 20 463-466. (doi:10.1016/08915849(96)02051-5)

Leos RA, Anderson MJ, Chen X, Pugmire J, Anderson KA \& Limesand SW 2010 Chronic exposure to elevated norepinephrine suppresses insulin secretion in fetal sheep with placental insufficiency and intrauterine growth restriction. American Journal of Physiology. Endocrinology and Metabolism 298 E770-E778. (doi:10.1152/ajpendo.00494.2009)

Limesand SW \& Hay WW Jr 2003 Adaptation of ovine fetal pancreatic insulin secretion to chronic hypoglycaemia and euglycaemic correction. Journal of Physiology 547 95-105. (doi:10.1113/jphysiol.2002.026831) 
Limesand SW, Rozance PJ, Zerbe GO, Hutton JC \& Hay WW Jr 2006 Attenuated insulin release and storage in fetal sheep pancreatic islets with intrauterine growth restriction. Endocrinology 147 1488-1497. (doi:10. 1210/en.2005-0900)

Limesand SW, Rozance PJ, Smith D \& Hay WW Jr 2007 Increased insulin sensitivity and maintenance of glucose utilization rates in fetal sheep with placental insufficiency and intrauterine growth restriction. American Journal of Physiology. Endocrinology and Metabolism 293 E1716-E1725. (doi:10.1152/ajpendo.00459.2007)

Maechler P, Jornot L \& Wollheim CB 1999 Hydrogen peroxide alters mitochondrial activation and insulin secretion in pancreatic beta cells. Journal of Biological Chemistry 274 27905-27913. (doi:10.1074/jbc.274.39. 27905)

Metzger BE, Lowe LP, Dyer AR, Trimble ER, Chaovarindr U, Coustan DR, Hadden DR, McCance DR, Hod M, McIntyre HD et al. 2008 Hyperglycemia and adverse pregnancy outcomes. New England Journal of Medicine 358 1991-2002. (doi:10.1056/NEJMoa0707943)

Mittelman SD, Van Citters GW, Kim SP, Davis DA, Dea MK, HamiltonWessler M \& Bergman RN 2000 Longitudinal compensation for fatinduced insulin resistance includes reduced insulin clearance and enhanced beta-cell response. Diabetes 49 2116-2125. (doi:10.2337/diabetes.49.12. 2116)

Most O \& Langer O 2007 GDM women in good glycemic control: which meal-related measure enhances fetal well-being? Journal of Perinatal Medicine 35 481-485. (doi:10.1515/JPM.2007.130)

Nakayama M, Inoguchi T, Sonta T, Maeda Y, Sasaki S, Sawada F, Tsubouchi H, Sonoda N, Kobayashi K, Sumimoto H et al. 2005 Increased expression of $\mathrm{NAD}(\mathrm{P}) \mathrm{H}$ oxidase in islets of animal models of type 2 diabetes and its improvement by an AT1 receptor antagonist. Biochemical and Biophysical Research Communications 332 927-933. (doi:10.1016/j.bbrc.2005.05.065)

National Research Council 2007 Nutrient Requirements of Small Ruminants: Sheep, Goats, Cervids, and New World Camelids. Washington, DC: National Academy Press.

Noda M, Yamashita S, Takahashi N, Eto K, Shen LM, Izumi K, Daniel S, Tsubamoto Y, Nemoto T, Iino M et al. 2002 Switch to anaerobic glucose metabolism with NADH accumulation in the beta-cell model of mitochondrial diabetes. Characteristics of betaHC9 cells deficient in mitochondrial DNA transcription. Journal of Biological Chemistry 277 41817-41826. (doi:10.1074/jbc.M207690200)

Obenshain SS, Adam PA, King KC, Teramo K, Raivio KO, Raiha N \& Schwartz R 1970 Human fetal insulin response to sustained maternal hyperglycemia. New England Journal of Medicine 283 566-570. (doi:10. 1056/NEJM197009102831104)

Oyadomari S \& Mori M 2004 Roles of CHOP/GADD153 in endoplasmic reticulum stress. Cell Death and Differentiation 11 381-389. (doi:10.1038/sj. cdd.4401373)

Parretti E, Mecacci F, Papini M, Cioni R, Carignani L, Mignosa M, La Torre P \& Mello G 2001 Third-trimester maternal glucose levels from diurnal profiles in nondiabetic pregnancies: correlation with sonographic parameters of fetal growth. Diabetes Care 24 1319-1323. (doi:10.2337/ diacare.24.8.1319)

Pettitt DJ, Bennet PH, Knowler WC, Baird R \& Aleck KA 1985 Gestational diabetes mellitus and impaired glucose tolerance during pregnancy: long term effects on obesity and glucose tolerance in the offspring. Diabetes 34 119-122.

Pi J, Bai Y, Zhang Q, Wong V, Floering LM, Daniel K, Reece JM, Deeney JT, Andersen ME, Corkey BE et al. 2007 Reactive oxygen species as a signal in glucose-stimulated insulin secretion. Diabetes 56 1783-1791. (doi:10.2337/ $\mathrm{db} 06-1601)$

Pildes RS, Hart RJ, Warrner R \& Cornblath M 1969 Plasma insulin response during oral glucose tolerance tests in newborns of normal and gestational diabetic mothers. Pediatrics 44 76-83.

Plagemann A, Harder T, Kohlhoff R, Rohde W \& Dorner G 1997 Glucose tolerance and insulin secretion in children of mothers with pregestational IDDM or gestational diabetes. Diabetologia 40 1094-1100. (doi:10.1007/ s001250050792)
Pribylova J \& Kozlova J 1979 Glucose and galactose infusions in newborns of diabetic and healthy mothers. Biology of the Neonate 36 193-197. (doi:10. 1159/000241227)

Richards OC, Raines SM \& Attie AD 2010 The role of blood vessels, endothelial cells, and vascular pericytes in insulin secretion and peripheral insulin action. Endocrine Reviews 31 343-363. (doi:10.1210/er.2009-0035)

Robertson RP 2007 Estimation of beta-cell mass by metabolic tests: necessary, but how sufficient? Diabetes 56 2420-2424. (doi:10.2337/db07-0742)

Robertson RP \& Harmon JS 2006 Diabetes, glucose toxicity, and oxidative stress: a case of double jeopardy for the pancreatic islet beta cell. Free Radical Biology \& Medicine 41 177-184. (doi:10.1016/j.freeradbiomed.2005.04. 030)

Rozance PJ, Limesand SW \& Hay WW Jr 2006 Decreased nutrientstimulated insulin secretion in chronically hypoglycemic late-gestation fetal sheep is due to an intrinsic islet defect. American Journal of Physiology. Endocrinology and Metabolism 291 E404-E411. (doi:10.1152/ajpendo.00643. 2005)

Sakai K, Matsumoto K, Nishikawa T, Suefuji M, Nakamaru K, Hirashima Y, Kawashima J, Shirotani T, Ichinose K, Brownlee M et al. 2003 Mitochondrial reactive oxygen species reduce insulin secretion by pancreatic beta-cells. Biochemical and Biophysical Research Communications 300 216-222. (doi:10.1016/S0006-291X(02)02832-2)

Schmittgen TD \& Livak KJ 2008 Analyzing real-time PCR data by the comparative $C(\mathrm{~T})$ method. Nature Protocols 3 1101-1108. (doi:10.1038/ nprot.2008.73)

Seaquist ER \& Robertson RP 1992 Effects of hemipancreatectomy on pancreatic alpha and beta cell function in healthy human donors. Journal of Clinical Investigation 89 1761-1766. (doi:10.1172/JCI115779)

Segar EM, Norris AW, Yao JR, Hu S, Koppenhafer SL, Roghair RD, Segar JL \& Scholz TD 2009 Programming of growth, insulin resistance and vascular dysfunction in offspring of late gestation diabetic rats. Clinical Science 117 129-138. (doi:10.1042/CS20080550)

Siegmund T, Rad NT, Ritterath C, Siebert G, Henrich W \& Buhling KJ 2008 Longitudinal changes in the continuous glucose profile measured by the CGMS in healthy pregnant women and determination of cut-off values. European Journal of Obstetrics, Gynecology, and Reproductive Biology 139 46-52. (doi:10.1016/j.ejogrb.2007.12.006)

Silverman BL, Metzger BE, Cho NH \& Loeb CA 1995 Impaired glucose tolerance in adolescent offspring of diabetic mothers. Relationship to fetal hyperinsulinism. Diabetes Care 18 611-617. (doi:10.2337/diacare.18.5.611)

Sobngwi E, Boudou P, Mauvais-Jarvis F, Leblanc H, Velho G, Vexiau P, Porcher R, Hadjadj S, Pratley R, Tataranni PA et al. 2003 Effect of a diabetic environment in utero on predisposition to type 2 diabetes. Lancet 361 1861-1865. (doi:10.1016/S0140-6736(03)13505-2)

Suhonen L, Hiilesmaa V \& Teramo K 2000 Glycaemic control during early pregnancy and fetal malformations in women with type I diabetes mellitus. Diabetologia 43 79-82. (doi:10.1007/s001250050010)

Takahashi H, Tran PO, LeRoy E, Harmon JS, Tanaka Y \& Robertson RP 2004 D-glyceraldehyde causes production of intracellular peroxide in pancreatic islets, oxidative stress, and defective beta cell function via nonmitochondrial pathways. Journal of Biological Chemistry 279 37316-37323. (doi:10.1074/jbc.M403070200)

Tanaka Y, Gleason CE, Tran PO, Harmon JS \& Robertson RP 1999 Prevention of glucose toxicity in HIT-T15 cells and Zucker diabetic fatty rats by antioxidants. PNAS 96 10857-10862. (doi:10.1073/pnas.96.19. 10857)

Tanaka Y, Tran PO, Harmon J \& Robertson RP 2002 A role for glutathione peroxidase in protecting pancreatic beta cells against oxidative stress in a model of glucose toxicity. PNAS 99 12363-12368. (doi:10.1073/pnas. 192445199)

Tang C, Han P, Oprescu AI, Lee SC, Gyulkhandanyan AV, Chan GN, Wheeler MB \& Giacca A 2007 Evidence for a role of superoxide generation in glucose-induced beta-cell dysfunction in vivo. Diabetes $\mathbf{5 6} 2722-2731$. (doi:10.2337/db07-0279)

Teixeira AS \& Andrade SP 1999 Glucose-induced inhibition of angiogenesis in the rat sponge granuloma is prevented by aminoguanidine. Life Sciences 64 655-662. (doi:10.1016/S0024-3205(98)00607-9) 
Tiedge M, Lortz S, Drinkgern J \& Lenzen S 1997 Relation between antioxidant enzyme gene expression and antioxidative defense status of insulin-producing cells. Diabetes 46 1733-1742. (doi:10.2337/diabetes.46. 11.1733)

Tsubouchi H, Inoguchi T, Inuo M, Kakimoto M, Sonta T, Sonoda N, Sasaki S, Kobayashi K, Sumimoto H \& Nawata H 2005 Sulfonylurea as well as elevated glucose levels stimulate reactive oxygen species production in the pancreatic beta-cell line, MIN6-a role of $\mathrm{NAD}(\mathrm{P}) \mathrm{H}$ oxidase in beta-cells. Biochemical and Biophysical Research Communications 326 60-65. (doi:10. 1016/j.bbrc.2004.10.201)

Van Assche FA, Holemans K \& Aerts L 2001 Long-term consequences for offspring of diabetes during pregnancy. British Medical Bulletin 60 173-182. (doi:10.1093/bmb/60.1.173) de Veciana M, Major CA, Morgan MA, Asrat T, Toohey JS, Lien JM \& Evans AT 1995 Postprandial versus preprandial blood glucose monitoring in women with gestational diabetes mellitus requiring insulin therapy. New England Journal of Medicine 333 1237-1241. (doi:10.1056/ NEJM199511093331901)

Received in final form 2 December 2011

Accepted 19 December 2011 Made available online as an Accepted Preprint 19 December 2011 